\title{
Responses in the microbial food web to increased rates of nutrient supply in a southern Chilean fjord: possible implications of cage aquaculture
}

\author{
Lasse Mork Olsen ${ }^{1, *}$, Klaudia L. Hernández ${ }^{2,3}$, Murat Van Ardelan ${ }^{4}$, \\ Jose Luis Iriarte ${ }^{5}$, Nicolas Sánchez ${ }^{4}$, Humberto E. González ${ }^{3,6}$, Nils Tokle ${ }^{1}$, \\ Yngvar Olsen ${ }^{1}$
}

\author{
${ }^{1}$ Norwegian University of Science and Technology, Dept. of Biology, 7491 Trondheim, Norway \\ ${ }^{2}$ Centro de Investigacion Marina Quintay CIMARQ, Facultad de Ecologia y Recursos Naturales, Universidad Andres Bello, \\ 2340000 Valparaiso, Chile \\ ${ }^{3}$ Universidad Austral de Chile, Instituto de Ciencias Marinas y Limnológicas, 5090000 Valdivia, Chile \\ ${ }^{4}$ Norwegian University of Science and Technology, Dept. of Chemistry, 7491 Trondheim, Norway \\ ${ }^{5}$ Instituto de Acuicultura and Centro de Investigación en Ecosistemas de la Patagonia-CIEP, Universidad Austral de Chile, \\ 5480000 Puerto Montt, Chile \\ ${ }^{6}$ Programa de Financiamiento Basal, COPAS Sur Austral, 4030000 Concepción, Chile
}

\begin{abstract}
Cage fish farms release the inorganic nutrients ammonium $\left(\mathrm{NH}_{4}\right)$ and phosphate $\left(\mathrm{PO}_{4}\right)$ into the surrounding water. The objectives of this experiment from the Comau fjord $\left(42.2^{\circ} \mathrm{S}\right)$ in southern Chile was to study how increased input of $\mathrm{NH}_{4}$ and $\mathrm{PO}_{4}$ to pelagic waters affects the biomass of defined functional groups of the microbial food web and the community composition of the micro-autotrophs. We used microcosms with $\mathrm{NH}_{4}$ and $\mathrm{PO}_{4}$ added in a gradient of concentrations, with the same N:P ratio as in aquaculture effluent. In addition, silicic acid was added in a 1:1 ratio with nitrogen to mimic the rich supply of silicon from both deep water and river water entering this fjord. A positive biomass response to nutrient loading rate was observed in the microautotroph, micro-heterotroph, and meso-heterotroph functional groups dominated by microphytoplankton, ciliates, and copepods, respectively. Silicon concentration was reduced to a low level, but the Si supply ratio maintained a dominance of diatoms. Biomass increase was accompanied by a succession in the diatom-dominated community towards large and elongated, possibly grazer-resistant species and some small elongated species adapted to silicon-limited conditions. Grazers had a role in the succession by removing successful non-elongated competitors. Silicon, which is not released by fish farms, played a crucial role in the phytoplankton response. With reduced freshwater input in Patagonia as predicted due to climate change, the supply of silicon to the productive zone below the brackish layer might be reduced, which could shift the phytoplankton community more in favor of dinoflagellates or other non-silicified species.
\end{abstract}

KEY WORDS: Eutrophication $\cdot$ Phytoplankton community $\cdot$ Microbial food web $\cdot$ Microcosm Patagonia $\cdot$ Chile

\section{INTRODUCTION}

In 2007, the total aquaculture production in Chile was close to $1000000 \mathrm{t}$, of which $73 \%$ was salmonid production in sea cages (Buschmann et al. 2009). This has introduced fish farms as new important sources

\footnotetext{
*Corresponding author: lasse.mork.olsen@ntnu.no
}

of potential anthropogenic eutrophication of the pelagic through the release of waste nutrients. The fish farms release inorganic nitrogen and phosphorus to the water column in the form of ammonium $\left(\mathrm{NH}_{4}\right)$ and phosphate $\left(\mathrm{PO}_{4}\right)$ excreted by the fish (Olsen \& Olsen 2008, Wang et al. 2012, 2013). For comparison, 
Norway has comparable production of farmed salmonids to Chile (Buschmann et al. 2009), and in coastal waters, the input of nitrogen from salmon aquaculture is 3 times higher than that from agriculture (Skarbøvik et al. 2012). In Chile, most of the production is located in the fjords in the south, in Chilean Patagonia. The areas surrounding many Patagonian fjords are not densely populated and therefore fish farms are presumably the main anthropogenic source of nutrients there. A fish farm which produces $10000 \mathrm{t}$ of fish per year produces the same amount of nutrients as a human population of about 100000 people (Olsen \& Olsen 2008). A farm of this size would be among the largest salmon farms by current industrial standards.

A recent stable isotope study concluded that increased carbon and nitrogen accumulation in the sediments in the Comau fjord in southern Chile during the last 2 decades was most likely due to aquaculture activities (Mayr et al. 2014). Considering that the density of fish farms in the inner seas of Chile is already high in some areas, there is potential for increased plankton production due to aquaculture if the industry continues to grow (Buschmann et al. 2009). It is therefore important to know how the planktonic food web will respond to increased nutrient loading rate, both to know the likely effects on the natural environment and the effects on aquaculture itself, e.g. fish farms and mussel farms.

Ecosystem-specific attributes may modify the responses to increased nutrient input in one area compared with another (Cloern 2001). One attribute could be the abundance and efficiency of predators feeding on the phytoplankton primary producers and heterotrophic bacteria that initially take up the nutrients. Olsen et al. $(2006,2007)$ concluded from a eutrophication mesocosm experiment in the northeast Atlantic that the main biomass response was in the nano- and micro-autotrophs, i.e. flagellates and diatoms, and that the main increase in carbon flow in the food web was through micro- and meso-heterotrophs, i.e. ciliates and copepods. In the Mediterranean Sea, these and other studies observed more efficient grazing that kept the biomass response in the autotrophs considerably lower (Olsen et al. 2006, 2007, Pitta et al. 2009).

The inherent natural nutrient ratios in a particular ecosystem may determine the composition of the communities of autotrophs, which in turn may affect how these communities respond to increased nutrient input. The southern fjord region of Chile is characterized by a low ratio of nitrate to phosphate in surface water, and nitrogen limitation is common (Iriarte et al. 2007, 2013). Fresh water in rivers that drain into the Comau fjord has relatively low concentration of inorganic phosphorus and nitrogen, but considerably more silicon (Iriarte et al. 2013). The ratio between total nitrogen and phosphorus may have a strong causal relationship with the community composition of phytoplankton (Philippart et al. 2000). Under eutrophic conditions when nitrogen is the limiting/ controlling nutrient, large diatoms are favored possibly because of a higher nutrient uptake rate and storage capacity of large cells (cf. Philippart et al. 2000). In addition to other nutrients, diatoms require silicon to build their frustules. Eutrophication by nitrogen and/or phosphorus may initially induce a diatom bloom when sufficient silicon is available because many diatom species are fast-growing (Conley et al. 1993), but because silicon is recycled slowly in the water column, other phytoplankton like flagellates and dinoflagellates could eventually become dominating under continuous loading with $\mathrm{N}$ and $\mathrm{P}$ (Conley et al. 1993).

The interplay between forcing factors like nutrient ratios and grazing rates will determine the eutrophication response in the food web. The objective of this microcosm experiment was to study how increased nutrient input to pelagic waters, as would occur from cage aquaculture, affects the biomass of defined functional groups of the microbial food web (Fig. 1), and the community composition of the micro-autotrophs. In order to answer these questions, we used 351 microcosms containing the natural plankton community incubated in situ in the Comau fjord in Chilean Patagonia $\left(42.2^{\circ} \mathrm{S}\right)$. Inorganic nutrients were added daily in a gradient with an ammonium to phosphate ratio similar to that coming from aquaculture and silicic acid added in a 1:1 ratio with nitrogen to mimic the rich supply of silicon in the Comau fjord. Copepods were the top consumers in our experiments and were added in equal amounts to all microcosms. Nutrient concentrations, the biomasses of the functional plankton groups, and the community composition of the micro-autotrophs were monitored for $16 \mathrm{~d}$.

\section{MATERIALS AND METHODS}

\section{Experimental setup}

The microcosm experiment was performed with natural seawater in the Comau fjord in Chilean Patagonia from 18 January to 3 February 2010. The incubation took place at the Huinay Field Station $\left(42^{\circ} 22^{\prime} \mathrm{S}, 72^{\circ} 24^{\prime} \mathrm{W}\right)$. 


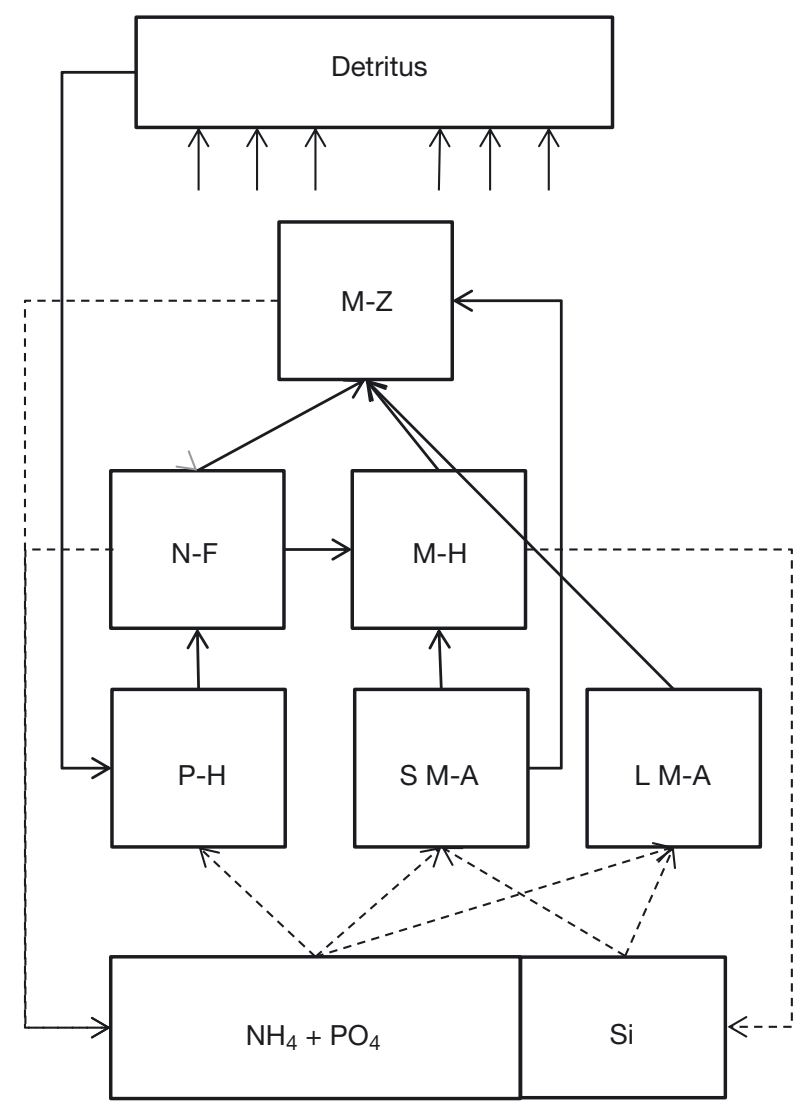

Fig. 1. Carbon biomass compartments of the plankton functional groups studied: small and large micro-autotrophs (S $\mathrm{M}-\mathrm{A}$ and L M-A), pico-heterotrophs (P-H), nanoflagellates (N-F), micro-heterotrophs (M-H), meso-heterotrophs, i.e. zooplankton (M-Z), and detritus. Solid lines denote the main carbon flows, and dashed lines show the flow of all inorganic nutrients: ammonium $\left(\mathrm{NH}_{4}\right)$, phosphate $\left(\mathrm{PO}_{4}\right)$, and silicon

(Si). Detritus is produced by the whole food web

For microcosms, we used 351 translucent white polyethylene containers. They were rinsed with $10 \%$ $\mathrm{HCl}$ and flushed with filtered seawater before use. To select sampling depth for the water used in the experiment, samples were taken about $125 \mathrm{~m}$ from the pier of the field station using a 51 Go-Flo bottle prewashed with $10 \% \mathrm{HCl}$. Salinity was checked with a refractometer. A brackish layer was found from the surface to a maximum depth of $5 \mathrm{~m}$. To ensure that we sampled full-salinity seawater, the sampled water was taken from $10 \mathrm{~m}$ depth with a Watson-Marlow $251 \mathrm{VI}$ industrial peristaltic pump with a $9.6 \mathrm{~mm}$ tube, and subsequently filtered through a $100 \mu \mathrm{m}$ net into a $1 \mathrm{~m}^{3}$ polyethylene container prewashed with seawater and used for mixing of the water before it was distributed to the 351 containers.

Zooplankton for addition to the microcosms were collected on the day before the start of the experiment by towing a WP-2 net with mesh size $200 \mu \mathrm{m}$ at
$20 \mathrm{~m}$ depth. Of the collected water, $60 \mathrm{l}$ were filtered and reverse concentrated through a $190 \mu \mathrm{m}$ mesh size sieve before larger zooplankton like gelatinous species and krill were removed. A subsample was counted to determine the concentration of copepods, and 0.51 was added to each microcosm to give a concentration of 0.25 ind. $\mathrm{l}^{-1}$, equal to the concentration in the sea at the time of sampling.

The containers were hung from a floating ring with a diameter of approximately $8 \mathrm{~m}$, with weights attached to keep them at $2 \mathrm{~m}$ depth at in situ temperature. Surface photosynthetically active radiation (PAR) was logged at the site with an Apogee quantum sensor equipped with a T\&D RVR 52A voltage recorder. The irradiance was reduced by $52 \%$ inside the containers compared with ambient light. The diffuse light attenuation coefficient for PAR was calculated from the measured Secchi depth (m) to be 1.7 (Poole \& Atkins 1929). Thus, calculated from the attenuation coefficient and measured irradiance, the maximum PAR inside the microcosms during the day according to the Beer-Lambert law varied between 70 and $350 \mu \mathrm{mol}$ photons $\mathrm{m}^{-2} \mathrm{~s}^{-1}$, depending on the cloud cover.

The microcosms were naturally mixed by the waves and the tide. Additional mixing was performed every day when each container was lifted out of the water and stirred before nutrient addition.

\section{Nutrient addition}

Ammonium in the form of $\mathrm{NH}_{4} \mathrm{Cl}$ was added in a gradient of 8 loading rates from 0 to $3.0 \mu \mathrm{mol} \mathrm{l}^{-1} \mathrm{~d}^{-1}$, phosphate $\left(\mathrm{NaH}_{2} \mathrm{PO}_{4}\right)$ was added in the range 0 to $0.11 \mu \mathrm{mol} \mathrm{l}^{-1} \mathrm{~d}^{-1}$ to a molar $\mathrm{N}: \mathrm{P}$ ratio of 28 , and silicon $\left(\mathrm{Na}_{2} \mathrm{SiO}_{3} \cdot 9 \mathrm{H}_{2} \mathrm{O}\right)$ was added in the range 0 to $3 \mu \mathrm{mol}$ $\mathrm{l}^{-1} \mathrm{~d}^{-1}$ (Table 1 ) to a molar N:Si ratio of 1 . We used this ratio of $\mathrm{Si}$ to allow diatoms to dominate the experi-

Table 1. Loading rates $\left(\mu \mathrm{mol} \mathrm{l^{-1 }} \mathrm{d}^{-1}\right)$ for ammonium $\left(L_{\mathrm{N}}\right.$, $\left.\mathrm{NH}_{4}-\mathrm{N} \mathrm{l}^{-1} \mathrm{~d}^{-1}\right)$, phosphate $\left(L_{\mathrm{P}}, \mathrm{PO}_{4}-\mathrm{P} \mathrm{l}^{-1} \mathrm{~d}^{-1}\right)$, and silicon

$\left(L_{\mathrm{Si}}, \mathrm{Na}_{2} \mathrm{SiO}_{3}-\mathrm{Si} \mathrm{l}^{-1} \mathrm{~d}^{-1}\right)$ in the 8 experimental treatments

\begin{tabular}{|lccc|}
\hline Treatment & $L_{\mathrm{N}}$ & $L_{\mathrm{P}}$ & $L_{\mathrm{Si}}$ \\
\hline 1 & 0.00 & 0.000 & 0.00 \\
2 & 0.30 & 0.019 & 0.30 \\
3 & 0.50 & 0.018 & 0.50 \\
4 & 0.70 & 0.025 & 0.70 \\
5 & 1.00 & 0.036 & 1.00 \\
6 & 1.40 & 0.050 & 1.40 \\
7 & 2.00 & 0.071 & 2.00 \\
8 & 3.00 & 0.107 & 3.00 \\
\hline
\end{tabular}


mental system because diatoms are known to dominate in these waters and to mimic the rich silicon supply from deep water and from rivers that drain into the fjord (Iriarte et al. 2007, 2013). Treatment 1 was a control with no nutrient addition, and Treatment 2 mimicked natural nutrient loading from deep water at the site with a molar N:P ratio of 16 and N:Si of 1 , i.e. the average natural ratio (Redfield 1958). For the other 6 treatments, $\mathrm{NH}_{4}-\mathrm{N}$ and $\mathrm{PO}_{4}-\mathrm{P}$ were added in a ratio typical of aquaculture effluent, forming a gradient of increasing nutrient loading rate (Table 1). For all 8 levels of nutrient addition there were 3 replicate microcosms, i.e. 24 containers in total. Nutrients were added manually in the afternoon every day, and on sampling days directly after sampling.

\section{Sampling and measurement of particulate organic carbon and nitrogen and inorganic nutrients}

Samples (1 1 each) were taken from each microcosm every second day throughout the experiment. From these samples, we took subsamples to determine dissolved nutrients (nitrate, nitrite, ammonium, phosphate, and silicate) and cell counts (phytoplankton, ciliates, heterotrophic flagellates, and bacteria) were taken from the microcosm containers every other day during the experiment. Samples for particulate organic carbon and nitrogen (POC and PON) and copepods were taken at Time 0 and at the end of the experiment (Day 16).

For POC and PON, water was filtered on precombusted $\left(450^{\circ} \mathrm{C}\right.$ for $\left.4 \mathrm{~h}\right) \mathrm{GFF} 0.45 \mu \mathrm{m}$ filters (Whatman) and kept at $-20^{\circ} \mathrm{C}$ until analysis. Two subsamples of the filters were packed in tin capsules, and carbon and nitrogen were measured in a Fisons Instruments auto-analyzer, model NA 1500 NC. Total
POC and PON per volume of water were calculated from the ratio of the area of the subsample to the total filter area normalized to volume filtered. Ammonium was immediately analyzed after collection following the indophenol-blue method (Grasshoff et al. 1983). Concentrations of nitrate and nitrite, phosphate, and silicic acid were measured in an auto-analyzer (Technicon) as described by Atlas et al. (1971) at the facilities of the Catholic University of Valparaiso, Chile.

\section{Plankton counts, identification, and biomass calculation}

Samples for plankton counts were taken from the first replicate for each nutrient loading treatment. Samples for phytoplankton counts were taken on Days $0,4,10$, and 16, samples for nanoflagellates on Days 2, 8, 10, and 16, and samples for pico-heterotrophs on Days 2, 6, 10, and 16. For phytoplankton, $250 \mathrm{ml}$ subsamples were fixed in $2 \%$ acid Lugol solution. Phytoplankton and ciliate cells were counted and measured after $24 \mathrm{~h}$ of settling in a sedimentation chamber of $10 \mathrm{ml}$ using inverted microscopy (WILD model 40) at 200 or $400 \times$ magnification (Utermöhl 1958). Phytoplankton was identified to the genus level, and biomass was determined using volume calculation described by Hillebrand et al. (1999) and conversion from volume to carbon biomass by the equations of Menden-Deuer \& Lessard (2000) for phytoplankton and ciliates (Table 2). For ciliates, we used an estimated average volume of $10000 \mu^{3} \mathrm{cell}^{-1}$, based on volume calculations performed in the detailed study of ciliates in the same experiment by Jensen (2012). The range of volumes was 5000 to 11000 , but after Day 8, the volume stabilized around $10000 \mu^{3}$.

Table 2. Functional groups in the microbial food web, dominating organisms in each group, and methods used to quantify the organisms and to estimate the carbon biomass

\begin{tabular}{|c|c|c|}
\hline Functional group & Dominating organisms & Quantification of biomass \\
\hline Small micro-autotrophs & Diatoms $<20 \mu \mathrm{m}$ & $\begin{array}{l}\text { Microscopy counts }{ }^{\mathrm{a}} \text {, volume calculations }{ }^{\mathrm{b}} \text {, } \\
\text { carbon:volume conversion }{ }^{\mathrm{c}}\end{array}$ \\
\hline Large micro-autotrophs & Diatoms $>20 \mu \mathrm{m}$ & Same as above \\
\hline Micro-heterotrophs & Ciliates $>10 \mu \mathrm{m}$ & Same as above \\
\hline Nanoflagellates & $\begin{array}{l}\text { Heterotrophic and autotrophic } \\
\text { flagellates }<20 \mu \mathrm{m}\end{array}$ & $\begin{array}{l}\text { Fluorescence microscopy counts } \\
\text { estimated volume }=35 \mu \mathrm{m}^{3, \mathrm{c}}, \mathrm{C}: \mathrm{Vol}^{\mathrm{c}}\end{array}$ \\
\hline Pico-heterotrophs & Heterotrophic bacteria $<2 \mu \mathrm{m}$ & $\begin{array}{l}\text { Fluorescence microscopy counts } \\
\text { carbon per cell }^{\mathrm{e}}=25 \mathrm{fg}^{\mathrm{f}}\end{array}$ \\
\hline Meso-heterotrophs & Copepods & Microscopy and length-weight ${ }^{g}$ \\
\hline
\end{tabular}


For bacterioplankton and nanoflagellate counts, water samples of $50 \mathrm{ml}$ from all microcosms were preserved with glutaraldehyde $(2 \% \mathrm{v} / \mathrm{v})$ and kept in the dark at $4^{\circ} \mathrm{C}$ until counting by epifluorescence microscopy with an Axiostar plus microscope (Zeiss). For counts of heterotrophic bacteria, 2 to $3 \mathrm{ml}$ of the samples were filtered onto $0.2 \mu \mathrm{m}$ black polycarbonate filters (Millipore) and stained with DAPI to a final concentration of $0.01 \% \mathrm{v} / \mathrm{v}$, according to Porter \& Feig (1980). For nanoflagellates, 20 to $30 \mathrm{ml}$ were filtered onto $0.8 \mu \mathrm{m}$ black polycarbonate filters (Millipore) and stained with Proflavine (3-6-diamidineacridine hemi-sulfate) to a final concentration of $0.033 \% \mathrm{w} / \mathrm{v}$, according to Hass (1982). Estimates of bacterioplankton and nanoflagellate biomasses were obtained using conversion factors of $25 \mathrm{fg} \mathrm{C} \mathrm{Cell}^{-1}$ for bacteria (Lee \& Fuhrman 1987), and conversion from volume to carbon biomass for flagellates by the equations in Menden-Deuer \& Lessard (2000) with an estimated average volume of $35 \mu^{3}$ (Table 2).

At the end of the experiment, the remaining water in the microcosms was filtered through a $200 \mu \mathrm{m}$ sieve and the volume was measured. The mesozooplankton and nauplii were preserved with $5 \%$ acid Lugol solution and counted under a microscope. The biomass was calculated from the length and weight relationship as described by Jensen (2012) (Table 2).

\section{Statistical analysis}

Linear regressions were performed in SigmaPlot 12. Regressions were considered significant if $p<0.05$. From the species data matrices from microscopy counts of phytoplankton, dissimilarity matrices were calculated, and based on these direct gradient analyses, we performed canonical correspondence analysis (CCA) in the R 2.9.1 platform (R Development Core Team 2008). Because data on $\mathrm{NH}_{4}$ concentration was not available for Day 16, the data from Day 14 were inserted. The significance of the constraints or axes was assessed by a permutation test (R documentation, Package vegan version 1.16-32). The Shannon diversity index for the phytoplankton community was calculated as: $H=-\operatorname{sum}\left(p_{i} \ln p_{i}\right)$, where $p_{i}$ is the proportion of individuals belonging to the $i^{\text {th }}$ species.

\section{RESULTS}

\section{Nutrient dynamics}

In water from $100 \mathrm{~m}$ depth approximately $100 \mathrm{~m}$ from the Huinay Field Station, we measured N:Si:P $(\mathrm{mol})=11: 8.5: 1, \mathrm{~N}: \mathrm{Si}=1.41, \mathrm{~N}=28 \mu \mathrm{M}, \mathrm{Si}=21 \mu \mathrm{M}$, and $\mathrm{P}=2.4 \mu \mathrm{M}$. In the initial water for our microcosm experiments taken at $10 \mathrm{~m}$ depth in the Comau fjord, the molar ratio between nitrate $(\mathrm{N})$, silicon $(\mathrm{Si})$ in the form of silicic acid $\left(\mathrm{H}_{2} \mathrm{SiO}_{4}\right)$, and phosphate $(\mathrm{P})$ was $\mathrm{N}: \mathrm{Si}: \mathrm{P}=10: 6: 1, \mathrm{~N}: \mathrm{Si}=1.69$, and concentrations were $\mathrm{N}=11.5 \mu \mathrm{M}, \mathrm{Si}=6.8 \mu \mathrm{M}, \mathrm{P}=1.1 \mu \mathrm{M}$ (Fig. 2). The concentration of $\mathrm{NO}_{2}$ was at maximum $10 \%$ of $\mathrm{NO}_{3}+$ $\mathrm{NO}_{2}$, but usually below $0.5 \%$ and 0 for most measurements. For brevity, we denote the sum of $\mathrm{NO}_{3}+$ $\mathrm{NO}_{2}$ simply as ' $\mathrm{NO}_{3}$ ' throughout the manuscript. After $4 \mathrm{~d}$, nitrate was totally depleted in all microcosms and remained so throughout the experiment, except for an increase in Treatments 1 and 8 on the last sampling day (Fig. 2). The concentration of ammonium initially increased on Day 2, but after this it stayed continuously in the range of 0.1 to $0.3 \mu \mathrm{M}$ throughout the experiment, except in Treatment 8 where it was maintained around $0.4 \mu \mathrm{M}$ (Fig. 2). Phosphate was also reduced to about $0.4 \mu \mathrm{M}$ after $4 \mathrm{~d}$ and showed values in the range of 0.2 to $0.6 \mu \mathrm{M}$ during the experiment, i.e. the nutrient was not depleted. For silicon, we found a rapid reduction at the start of the experiment, and the concentration in all treatments remained low (between 0 and $1 \mu \mathrm{M}$ ) throughout the experiment (Fig. 2). The average concentration of phosphate during the experiment was positively correlated with the loading rate $\left(R^{2}=0.46\right.$, $\mathrm{p}<0.05)$ whereas nitrate, ammonium, and silicon were not. The standard errors of the mean were in the range of 6 to $23 \%$ for phosphate, 12 to $82 \%$ for silicon, 5 to $77 \%$ for nitrate, and 13 to $45 \%$ for ammonium.

\section{Carbon biomass response of functional groups to nutrient addition}

Small micro-autotrophs

From the measurements of cell volumes of the identified phytoplankton groups, we defined a functional group comprising small micro-autotrophs as those having a volume per cell $<10000 \mu^{3}$, and large micro-autotrophs as those larger than that. In the initial water for the experiment, the biomass of small micro-autotrophs was $18 \mu \mathrm{g} \mathrm{Cl}^{-1}$ (Fig. 3a). The biomass increased to $50-80 \mu \mathrm{C} \mathrm{Cl}^{-1}$ between Days 0 and 4 in all microcosms. On Day 10, the biomass had decreased slightly in most treatments, but it increased in Treatments 3, 6, and 8 (Fig. 3a). No significant linear relationship with ammonium loading rate was found (Table 3). On Day 16, the biomass was still generally in the same range $\left(20-100 \mu \mathrm{g} \mathrm{C}^{-1}\right)$, but 
a) Phosphate

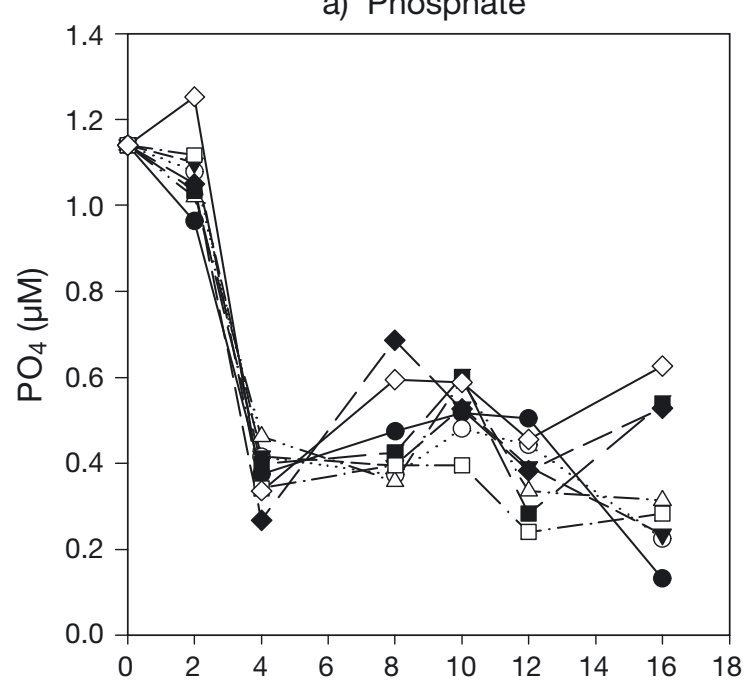

c) Nitrate

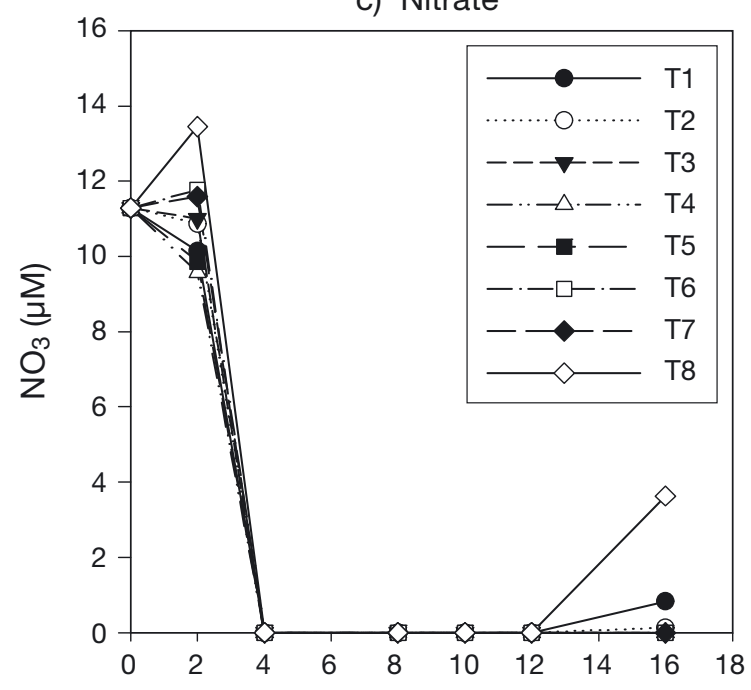

b) Silicon

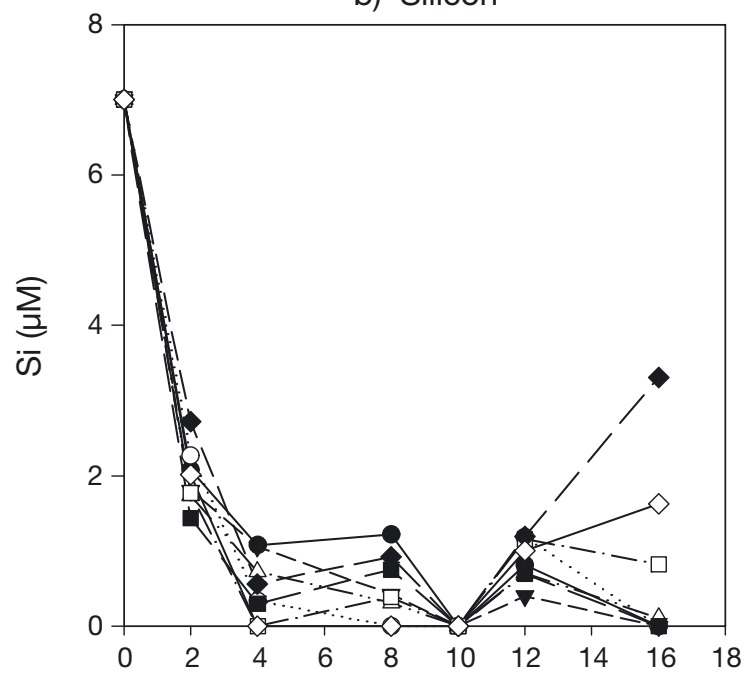

d) Ammonium

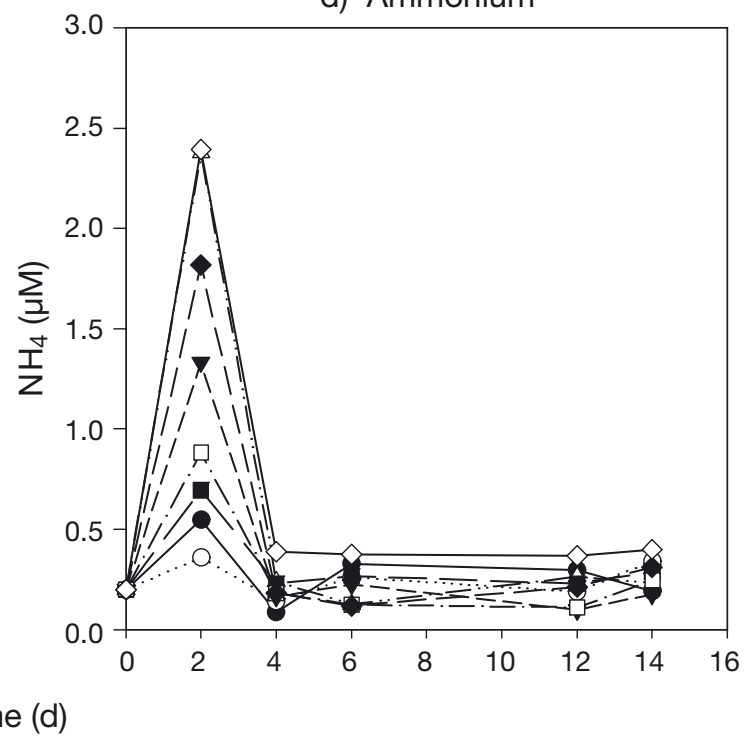

Fig. 2. Development of the average $(n=3)$ concentration $(\mu M)$ of $(a)$ dissolved phosphate, $(b)$ silicon, (c) nitrate, and $(d)$ ammonium over time in the 8 treatments (T1-T8, see Table 1) of the experiment. The standard errors of the mean were in the range $6-23 \%$ for phosphate, $12-82 \%$ for silicon, $5-77 \%$ for nitrate, and $13-45 \%$ for ammonium

now there was a stronger and significant relationship between biomass and the loading rate of ammonia (Table 3). The average biomass of small microautotrophs during the experiment had a significant positive linear relation with the loading rate of ammonia (Table 3).

\section{Large micro-autotrophs}

The initial biomass of large micro-autotrophs was $8 \mu \mathrm{g} \mathrm{l}^{-1}$ (Fig. 3b). The largest micro-autotroph identified in our samples were Coscinodiscus sp., which has about 14 times larger volume than the second largest, Rhizosolenia sp. Even low numbers of these cells made a large contribution to the phytoplankton biomass in the microcosms. When included, the biomass of Coscinodiscus sp. dominated in Treatments 4,6 , and 7 on Day 4, in all treatments except Treatment 8 on Day 10, and in Treatments 3 and 4 on Day 16. We found no linear relationship between large micro-autotroph biomass and ammonium loading rate. Because of the very large biomass of the few cells of Coscinodiscus sp. compared with all other phytoplankton, we looked for trends in biomass of large micro-autotrophs without Coscinodiscus sp. 
a) Small micro-autotrophs

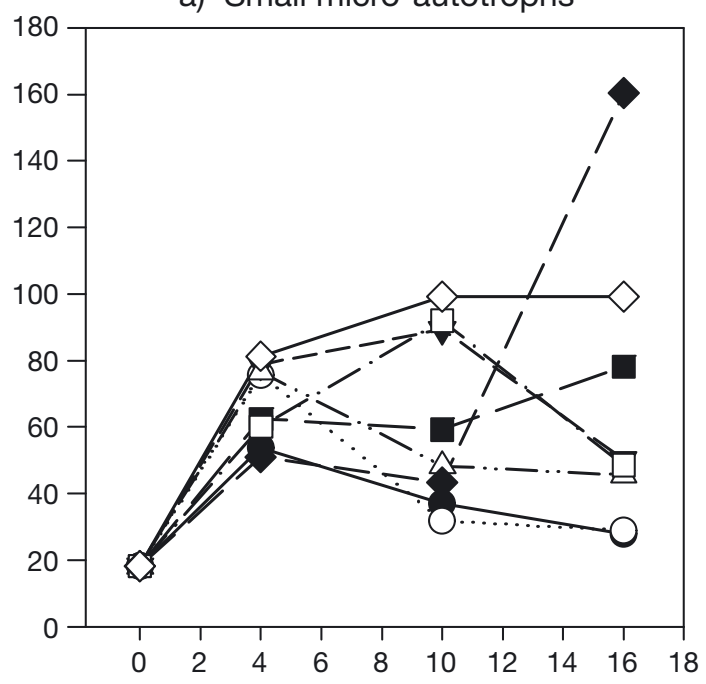

c) Nanoflagellates

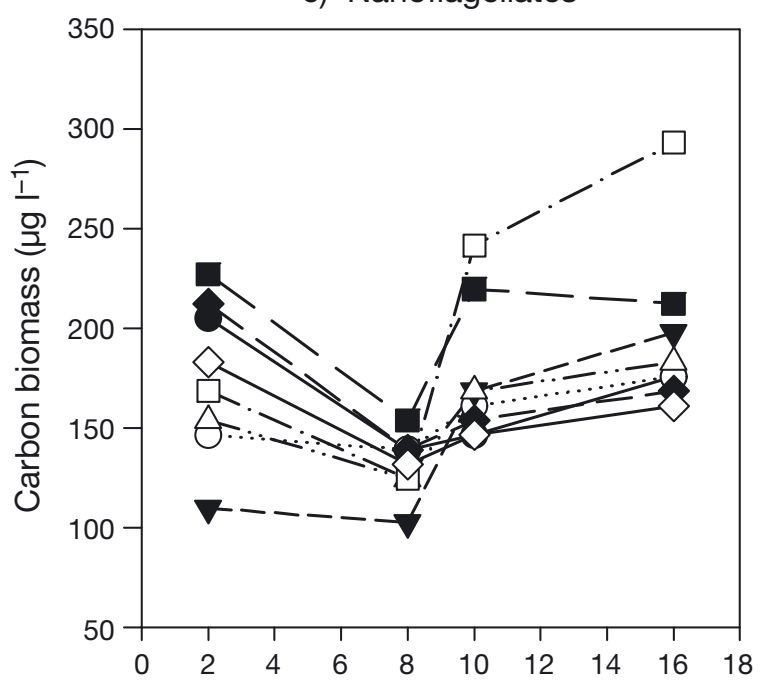

e) Micro-heterotrophs

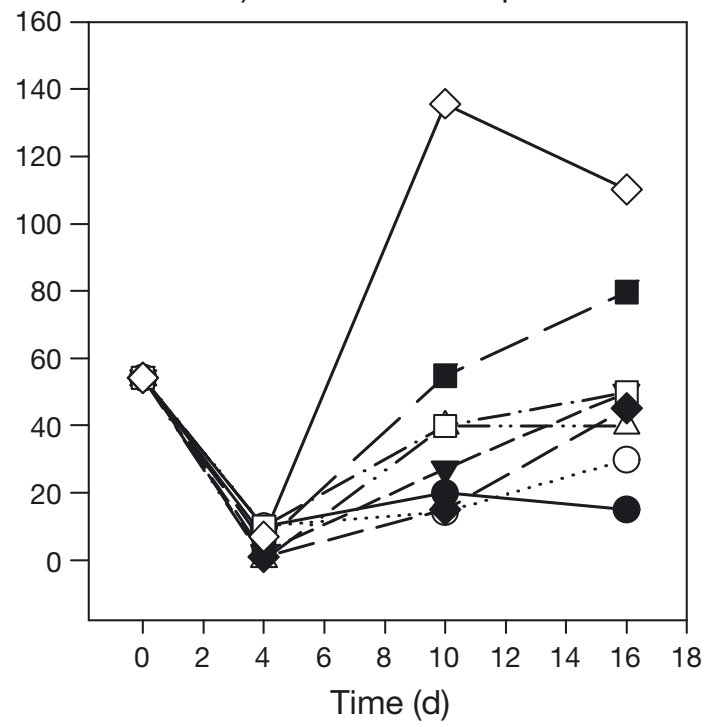

b) Large micro-autotrophs

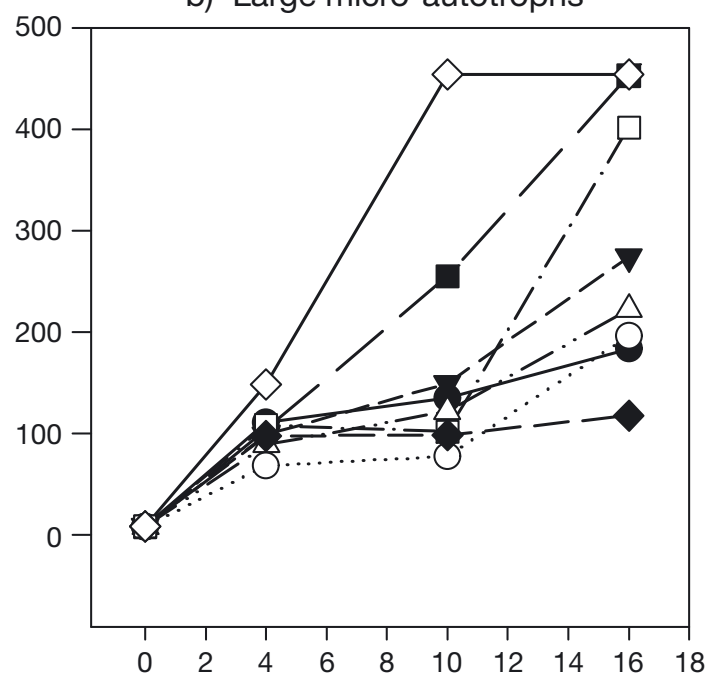

d) Pico-heterotrophs
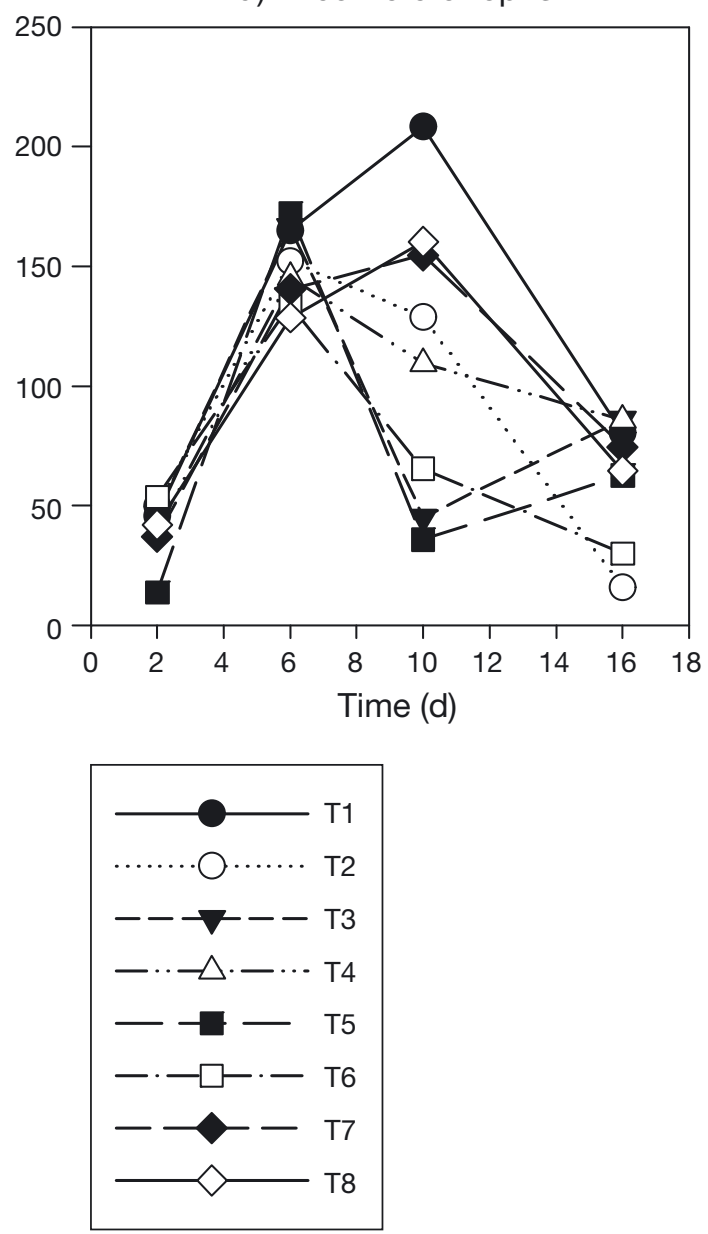

Fig. 3. Time development of the carbon biomass $\left(\mu g \mathrm{Cl}^{-1}\right)$ of each functional group in the food web for each experimental treatment (T1-T8, see Table 1): (a) small micro-autotrophs, (b) large micro-autotrophs, (c) nanoflagellates, (d) picoheterotrophs, (e) micro-heterotrophs 
Table 3. Carbon biomass versus nitrogen loading rate $\left(L_{N}\right)$ linear regressions. Intercept and slope $\pm \mathrm{SE}, \mathrm{R}^{2}$ and $\mathrm{p}$-value for small and large microautotrophs (S M-A and L M-A), nanoflagellates (N-F), pico-heterotrophs (P-H), micro-heterotrophs (M-H), copepods (COP), copepod nauplii (Nau), particulate organic carbon (POC), and detritus (Detr). Day number (d)

\begin{tabular}{|c|c|c|c|c|}
\hline Regression & Intercept & Slope & $\mathrm{R}^{2}$ & $\mathrm{p}$ \\
\hline S M-A vs. $\mathrm{L}_{\mathrm{N}} \mathrm{d} 4$ & $66.17 \pm 7.13$ & $1.14 \pm 4.92$ & 0.0089 & 0.8243 \\
\hline S M-A vs. $L_{N}$ d10 & $45.76 \pm 13.41$ & $15.05 \pm 9.26$ & 0.3056 & 0.1553 \\
\hline S M-A vs. $L_{N}$ d16 & $30.06 \pm 17.79$ & $33.49 \pm 12.28$ & 0.5536 & 0.0343 \\
\hline S M-A vs. $L_{N}$ Avg & $40.02 \pm 3.64$ & $0.23 \pm 0.05$ & 0.8029 & 0.0026 \\
\hline L M-A vs. $\mathrm{L}_{\mathrm{N}} \mathrm{d} 4$ & $85.43 \pm 9.66$ & $16.00 \pm 6.67$ & 0.4898 & 0.0533 \\
\hline L M-A vs. $\mathrm{L}_{\mathrm{N}} \mathrm{d} 10$ & $79.10 \pm 54.89$ & $85.61 \pm 37.89$ & 0.4597 & 0.0646 \\
\hline L M-A vs. $\mathrm{L}_{\mathrm{N}} \mathrm{d} 16$ & $223.22 \pm 70.14$ & $58.32 \pm 48.42$ & 0.1947 & 0.2738 \\
\hline L M-A vs. $L_{N}$ Avg & $99.04 \pm 29.71$ & $0.75 \pm 0.38$ & 0.3878 & 0.0991 \\
\hline N-F vs. $L_{N}$ d2 & $162.97 \pm 22.20$ & $11.48 \pm 15.33$ & 0.0855 & 0.4822 \\
\hline N-F vs. $L_{N}$ d6 & $130.38 \pm 9.01$ & $1.28 \pm 6.22$ & 0.0070 & 0.8442 \\
\hline N-F vs. $L_{N}$ d10 & $177.16 \pm 21.12$ & $-1.28 \pm 14.58$ & 0.0013 & 0.9331 \\
\hline N-F vs. $L_{N}$ d16 & $199.27 \pm 25.26$ & $-3.06 \pm 17.43$ & 0.0051 & 0.8667 \\
\hline N-F vs. $L_{N}$ Avg & $167.45 \pm 13.63$ & $0.04 \pm 0.18$ & 0.0083 & 0.8304 \\
\hline P-H vs. $L_{N} d 2$ & $42.79 \pm 7.23$ & $-1.53 \pm 4.99$ & 0.0154 & 0.7695 \\
\hline P-H vs. $L_{N}$ d6 & $163.85 \pm 6.50$ & $-11.99 \pm 4.49$ & 0.5437 & 0.0369 \\
\hline P-H vs. $L_{N}$ d10 & $106.18 \pm 36.22$ & $6.58 \pm 25.00$ & 0.0114 & 0.8011 \\
\hline P-H vs. $\mathrm{L}_{\mathrm{N}} \mathrm{d} 16$ & $62.58 \pm 15.60$ & $-0.07 \pm 10.77$ & 0.000007 & 0.9951 \\
\hline P-H vs. $\mathrm{L}_{\mathrm{N}} \mathrm{Avg}$ & $93.85 \pm 10.48$ & $-0.03 \pm 0.14$ & 0.0097 & 0.8167 \\
\hline $\mathrm{M}-\mathrm{H}$ vs $\mathrm{L}_{\mathrm{N}} \mathrm{d} 4$ & $6.34 \pm 2.46$ & $-0.66 \pm 1.70$ & 0.0244 & 0.7118 \\
\hline$M-H$ vs $L_{N}$ d10 & $9.71 \pm 15.72$ & $30.16 \pm 10.85$ & 0.5627 & 0.0320 \\
\hline$M-H$ vs $L_{N}$ d16 & $25.65 \pm 10.66$ & $24.01 \pm 7.36$ & 0.6397 & 0.0172 \\
\hline M-H vs $L_{N}$ Avg & $88.11 \pm 23.24$ & $0.92 \pm 0.30$ & 0.6102 & 0.0221 \\
\hline Cop vs. $L_{N} d 16^{a}$ & $22.28 \pm 5.16$ & $8.34 \pm 3.56$ & 0.4777 & 0.0577 \\
\hline Nau vs. $L_{N} d 16^{a}$ & $0.29 \pm 0.07$ & $0.53 \pm 0.07$ & 0.9214 & 0.0006 \\
\hline POC vs. $L_{N}$ d16 & $981.17 \pm 129.10$ & $350.67 \pm 89.11$ & 0.7207 & 0.0077 \\
\hline Detr vs. $L_{N}$ d16 & $417.56 \pm 97.18$ & $229.50 \pm 67.08$ & 0.6611 & 0.0141 \\
\hline
\end{tabular}
or averages $(\mathrm{Avg})$ are given. Significant $(\mathrm{p}<0.05)$ regressions are in bold

showed a biomass between 124 and $293 \mu \mathrm{g} \mathrm{Cl}^{-1}$ (Fig. 3c). No linear relationship between the nanoflagellate biomass and nutrient loading rate could be detected at any sampling time or for the average biomass during the experiment (Table 3).

Pico-heterotrophs (heterotrophic bacteria)

On Day 2 of the experiment, the biomass of heterotrophic bacteria varied between 14 and $54 \mu \mathrm{g} \mathrm{C}^{-1}$ in the microcosms (Fig. 3d). From Days 2 to 6, there was a pronounced increase in biomass to 129-172 $\mu \mathrm{g} \mathrm{C} \mathrm{C}^{-1}$ in the microcosms, but up to Day 10 there was a decrease in bacterial biomass for most treatments and a slight increase in others. On Day 16, all microcosms exhibited a lower biomass than during the peak. The biomass at this time was in the range of 16 to $86 \mu \mathrm{g} \mathrm{C} \mathrm{l}^{-1}$ (Fig. 3d). There was no significant relationship between bacterial biomass and ammonium loading rate except for a negative relationship at Day 6 (Table 3).

\section{Micro-heterotrophs (ciliates)}

The initial biomass of ciliates was $54 \mu \mathrm{g}$ $\mathrm{C}^{-1}$ (Fig. 3e), and the biomass dropped to $1-10 \mu \mathrm{g} \mathrm{Cl}^{-1}$ in all treatments on Day 4 after which there was an increase up to and found a positive trend with ammonium loading rate on Days 4 and 10 (Table 3). The poor correlation with ammonium loading rate on Day 16 was mainly due to Treatment 7 , which showed much lower biomass than the other treatments (Fig. 3b). Without Treatment 7 included, the linear relationship with loading rate was better $\left(\mathrm{R}^{2}=0.63, \mathrm{p}=0.033\right)$. For the average large micro-autotroph biomass, we found no significant linear relation with ammonia loading rate (Table 3).

Nanoflagellates (heterotrophic and autotrophic)

The biomass of nanoflagellates varied in the range of 110 to $227 \mu \mathrm{C} \mathrm{l}^{-1}$ already on Day 2 (Fig. 3c). In most of the microcosms, flagellate biomass varied

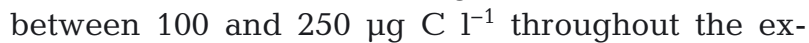
periment, with the exception of Treatment 6 , which
Day 10 for all treatments, with a linear, significant relationship between ammonium loading rate and ciliate biomass (Table 3). For most treatments, the biomass continued to increase up to Day 16, but the rate of increase was lower than earlier (Fig. 3e). The range in biomass on Day 16 was 15 to $110 \mu \mathrm{g} \mathrm{Cl}^{-1}$, and a linear relationship between ammonium loading rate and ciliate biomass was apparent (Table 3). The average biomass response of micro-heterotrophs was positively related with ammonia loading rate (Table 3).

On Day 16, POC varied between 0.8 and $2.1 \mathrm{mg} \mathrm{C}$ $\mathrm{I}^{-1}$, and there was a positive linear relationship with nutrient loading rate $\left(\mathrm{R}^{2}=0.72, \mathrm{p}=0.012\right.$, Fig. $\left.4 \mathrm{a}\right)$. Total biotic carbon calculated as the sum of the esti-

\section{Total POC}



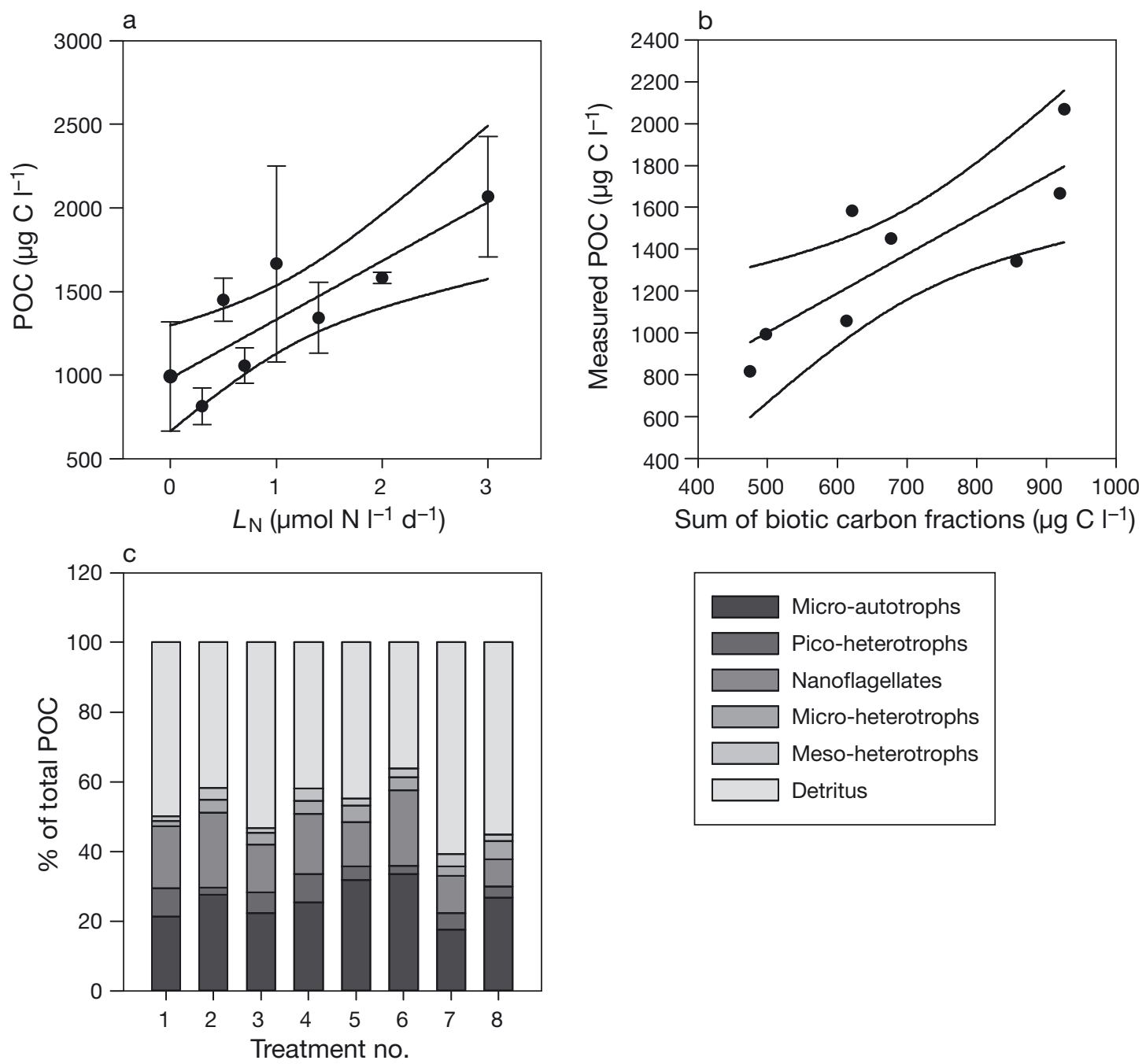

Fig. 4. (a) Average $(\mathrm{n}=3)$ particulate organic carbon $\left(\mathrm{POC}, \mu \mathrm{C} \mathrm{Cl}^{-1}\right)$ as a function of nutrient loading rate $\left(L_{\mathrm{N}}, \mu \mathrm{mol} \mathrm{NH} \mathrm{l}_{4} \mathrm{l}^{-1} \mathrm{~d}^{-1}\right)$ at the final sampling (Day 16), with a positive linear relationship with nutrient loading rate $\left(\mathrm{R}^{2}=0.72, \mathrm{p}=0.012\right)$. The linear regression line is shown with $95 \%$ confidence intervals and bars denoting \pm 1 SE. (b) POC plotted against total biotic carbon calculated as the sum of the estimated carbon biomass of the organism fractions, with linear regression line with $95 \%$ confidence lines: $\left(\right.$ measured POC) $=1.86 \times\left(\right.$ estimated POC) $-68.88, R^{2}=0.68, p=0.012$. (c) Percent composition of the functional plankton groups on Day 16 (see Table 1 for details on treatments)

mated carbon biomass of the organisms was linearly related to the measured POC concentration $\left(\mathrm{R}^{2}=\right.$ $0.68, \mathrm{p}=0.012$, Fig. 4b). The difference between measured POC and the sum of biotic fractions is an estimate of detritus, which in the range of 494 to $1142 \mu \mathrm{g} \mathrm{C}{ }^{-1}$ constituted between 42 and $55 \%$ of total POC (Fig. 4c).

Fig. 4c shows the percent composition of the functional plankton groups on Day 16. The average contribution of the groups to total biotic carbon biomass was $10 \%$ nano-autotrophs, $40 \%$ micro-autotrophs, $9 \%$ pico-heterotrophs, $29 \%$ nanoflagellates, $7 \%$ micro-heterotrophs, and 5\% meso-heterotrophs. The fraction of total biotic biomass that was auto- trophs was on average $50 \%$. The autotroph to heterotroph ratio was in the range of 0.74 to 1.48 , and a regression with nutrient loading rate resulted in a weak linear increase in the fraction of autotrophs with increasing loading rate $\left(\mathrm{R}^{2}=0.41, \mathrm{p}=0.088\right)$. The total autotroph biomass showed a weak linear relation with nutrient loading rate $\left(\mathrm{R}^{2}=0.44, \mathrm{p}=\right.$ 0.072) with a slope of $92 \mu \mathrm{g} \mathrm{C}(\mu \mathrm{mol} \mathrm{N})^{-1} \mathrm{~d}^{-1}$, and summed heterotrophs were even weaker $\left(R^{2}=0.31\right.$, $\mathrm{p}=0.15)$ with a slope of $29 \mu \mathrm{g} \mathrm{C}(\mu \mathrm{mol} \mathrm{N})^{-1} \mathrm{~d}^{-1}$. The concentration of detritus showed a stronger and significant correlation with nutrient loading $\left(\mathrm{R}^{2}=0.66\right.$, $\mathrm{p}=0.014)$ and a considerably higher slope of $230 \mu \mathrm{g}$ $\mathrm{C}(\mu \mathrm{mol} \mathrm{N})^{-1} \mathrm{~d}^{-1}$. 


\section{Diversity and community composition of micro-autotrophs}

In the initial water, the Shannon diversity index $(H)$ for the total phytoplankton community of small and large micro-autotrophs was 0.67 (Fig. 5). On Day 4, the index had increased in all treatments to between 0.86 and 1.43. On Day 10, the value of $H$ was in the range of 0.91 to 2.04 , with a significant positive linear relationship between $H$ and nitrogen loading rate, $L_{N}$ $(p=0.0028)$. On Day 16 , the diversity index was in the same range as on Day 10, but it did not correlate with $L_{N}$. In the CCA of phytoplankton counts at the genus level with $L_{\mathrm{N}}$ as the only environmental constraint, a significant relationship between community composition and $L_{\mathrm{N}}$ was found on Day $10(\mathrm{p}=0.005)$, while it was non-significant on Day $16(p=0.14)$. In the CCA with community data from Days 10 and 16, with all environmental variables included, $85 \%$ of the mean squared contingency coefficient (the inertia, or variance) was constrained by the components, or axes, i.e. by the set of environmental variables (Fig. 6). The proportion of the variance explained by the first 2 components was $61 \%$, and of the constrained part of the variance, the first 2 axes covered $72 \%$. The permutation test for CCA indicated significance of the constraints on microbial community structure when all environmental variables were included $(\mathrm{p}=0.005)$. When testing for individual environmental variables as constraints, $\mathrm{PO}_{4}$, bacterial, nanoflagellate, and ciliate abundances were not significant. All other constraints (phytoplankton abundance, $\mathrm{NO}_{3}, \mathrm{Si}, \mathrm{NH}_{4}$, and $\mathrm{NH}_{4}$ loading rate $\left[L_{\mathrm{N}}\right]$ ) were significant, with $\mathrm{p}<0.05$.

Succession of the community of small micro-autotrophs

The micro-autotroph community was dominated by diatoms both at Time 0 and during the experiment (Fig. 7). Skeletonema sp. initially completely dominated in cell number of small micro-autotrophs in the water used for the experiment. In all microcosms, Skeletonema sp. increased from the initial cell concentration of 290 cells ml ${ }^{-1}$ to around 1000 cells ml $^{-1}$ on Day 4 and then the number decreased around $50 \%$ to Day 10 and almost to 0 on Day 16 at all nutrient loading rates. Chaetoceros sp. increased from the initial 12 cells ml ${ }^{-1}$ to between 100 and 500 cells ml${ }^{-1}$, showing maximum numbers on Days 4 or 10, thereafter decreasing to 0 cells on Day 16 in all mesocosms. Thalassionema sp. was present with only 2 cells $\mathrm{ml}^{-1}$ on Day 0, but increased to about $400-600$ cells ml ${ }^{-1}$ in all

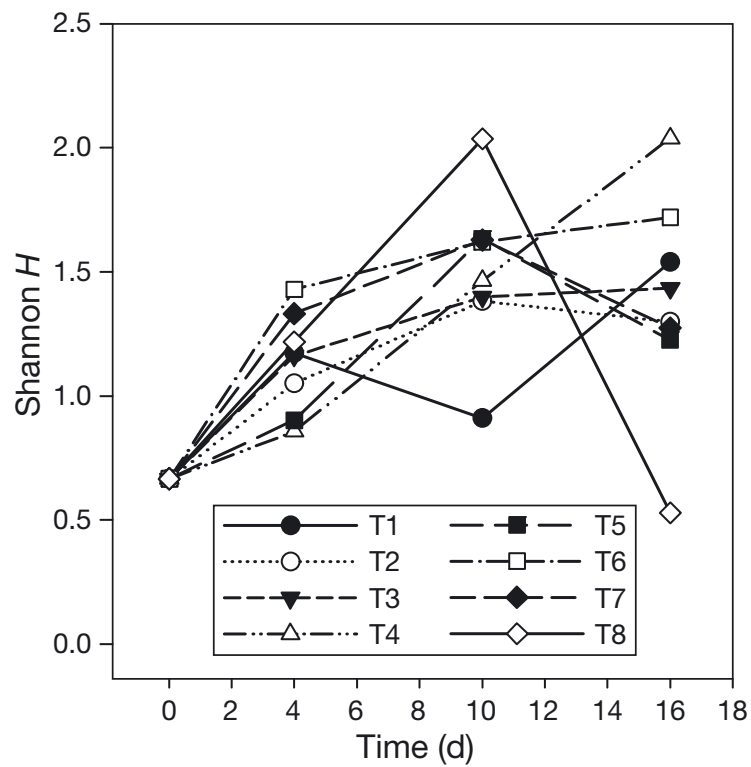

Fig. 5. Time development of the Shannon diversity index for the total micro-autotroph community for each nutrient loading treatment (T1-T8, see Table 1)

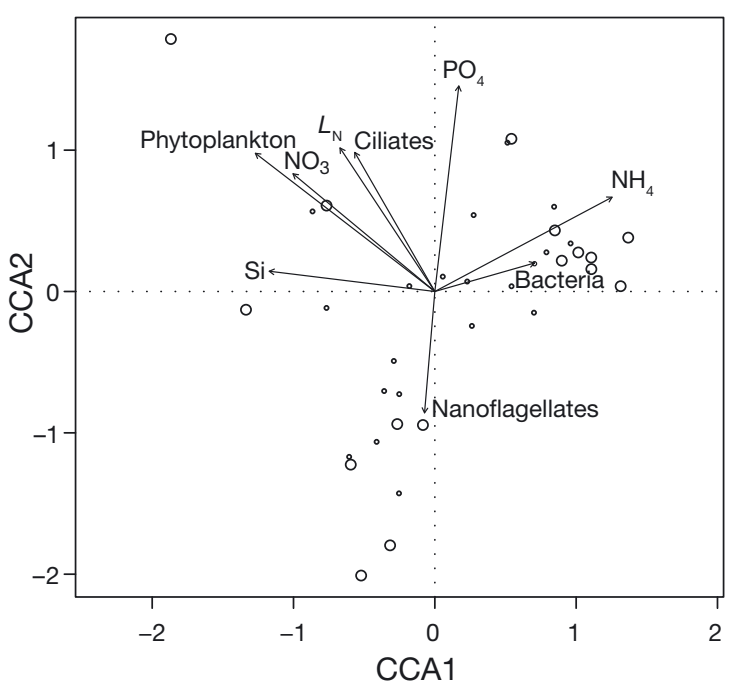

Fig. 6. Canonical correspondence analysis (CCA) of phytoplankton counts at the genus level on Days 10 and 16 of the experiment. The genera are indicated by small circles and the samples by bigger circles. Of the mean squared contingency coefficient (variance), $85 \%$ was constrained by the components, i.e. by the environmental variables. The proportion of the variance explained by the first 2 components was $61 \%$, and of the constrained part of the variance, the 2 first axes covered $72 \%$. The permutation test for CCA indicated significance of the constraints on microbial community structure when all constraints (environmental variables) were included $(p=0.005)$. When testing for individual environmental variables as constraints, $\mathrm{PO}_{4}$ and bacterial, nanoflagellate, and ciliate abundance were not significant. All other constraints were significant with $\mathrm{p}<0.05$ 
a) Small Micro-Autotrophs, Day 4

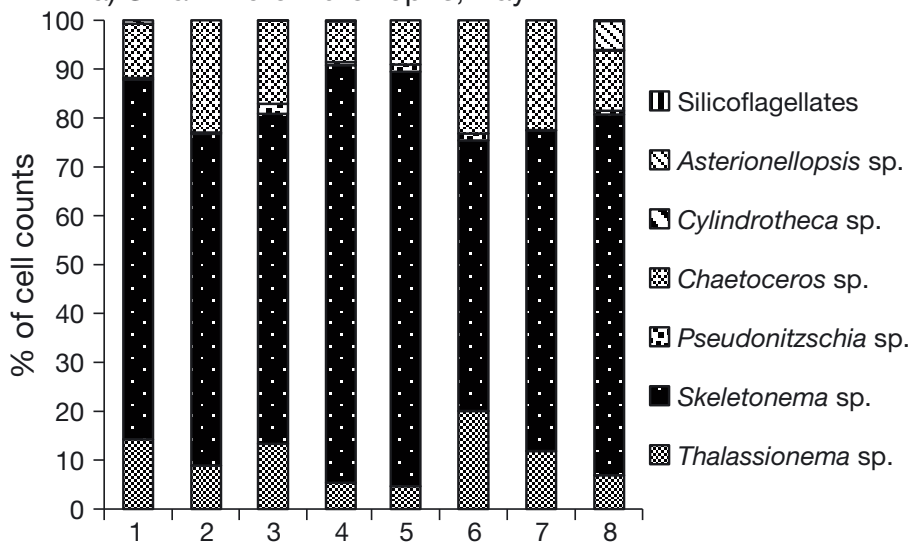

b) S M-A, Day 10

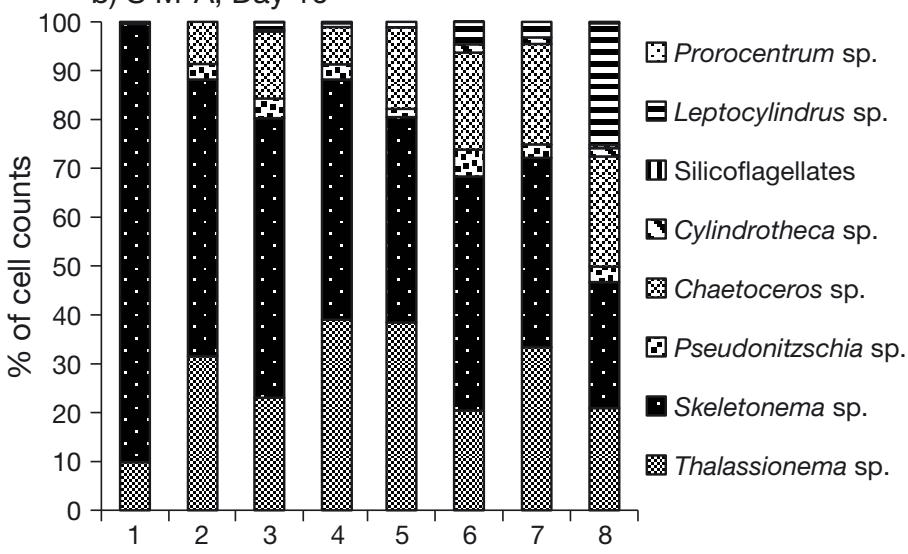

c) S M-A, Day 16

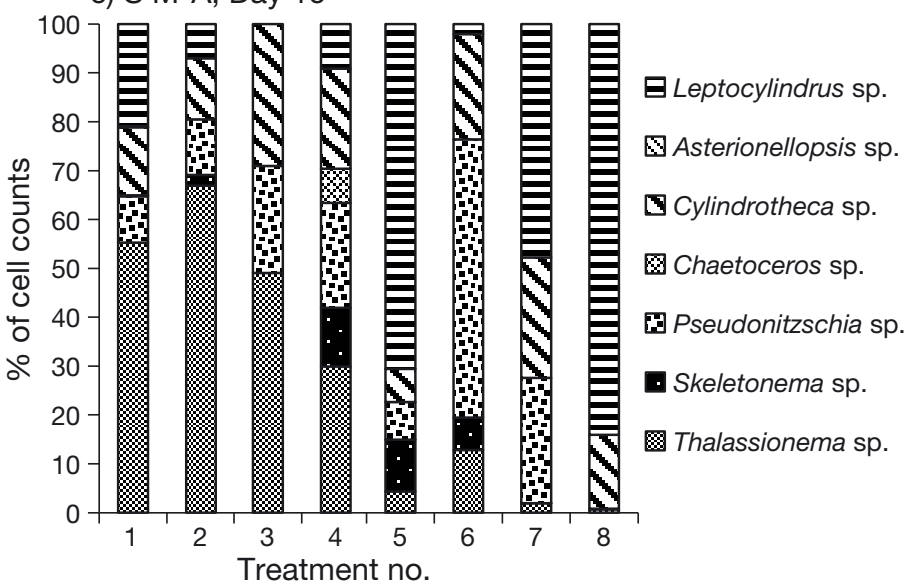

d) Large Micro-Autotrophs, Day 4

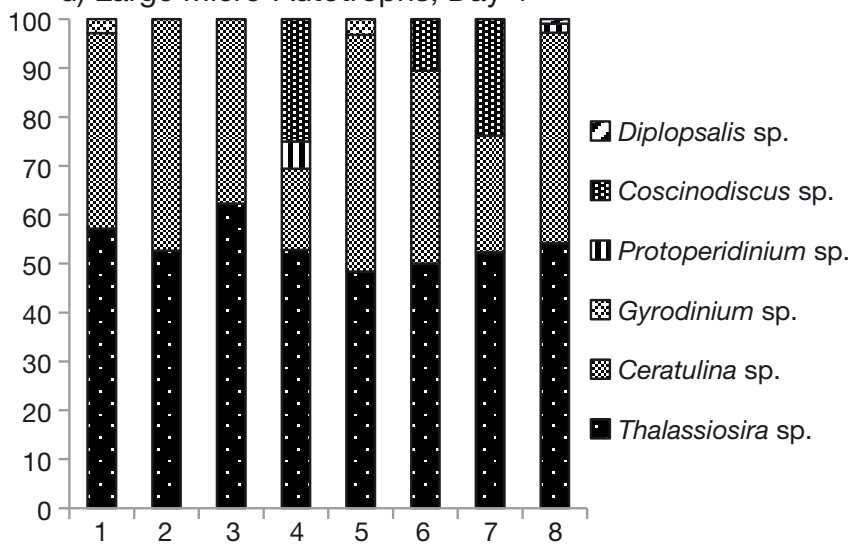

e) L M-A, Day 10

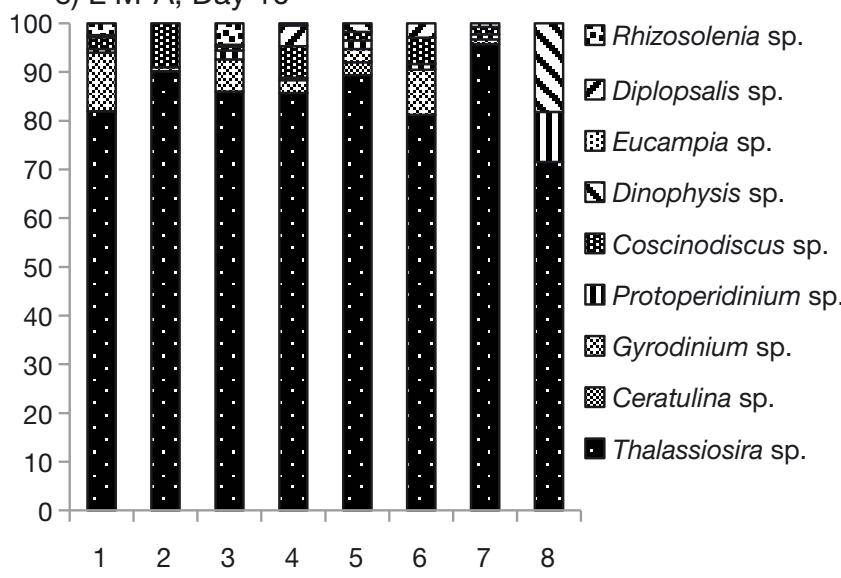

f) L M-A, Day 16

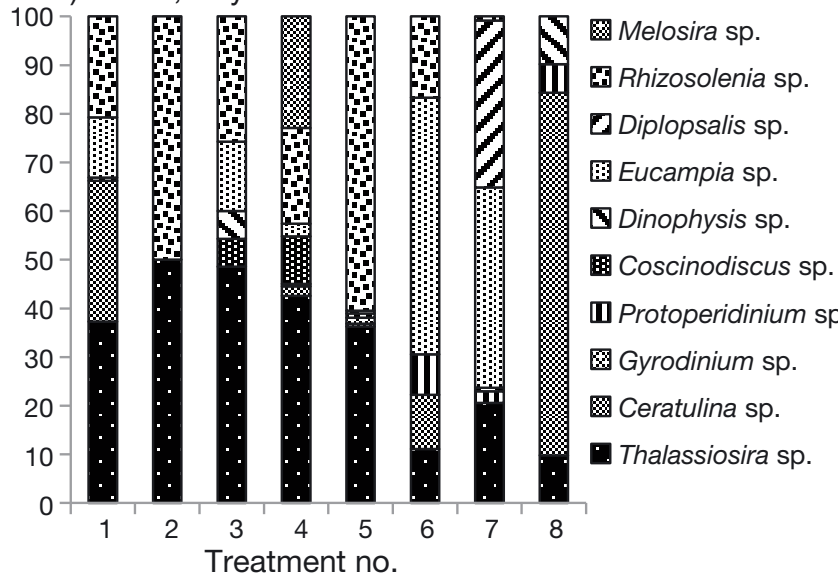

Fig. 7. Percent composition of the small and large micro-autotroph communities on (a,d) Day 4, (b,e) Day 10, and (c,f) Day 16

mesocosms, reaching a maximum cell number on Day 16 in the low $L_{\mathrm{N}}$ mesocosms (T1-T3) and on Day 10 in the high $L_{\mathrm{N}}$ mesocosms (T4-T8) before a rapid decline to Day 16. In the high $L_{\mathrm{N}}$ mesocosms, the number of Leptocylindrus sp. increased from very low numbers to 2000-8000 cells $\mathrm{ml}^{-1}$ between Days 10 and 16. Also, Cylindrotheca sp. and Pseudonitzschia sp. increased from very low numbers to be- come dominant in cell numbers towards the end of the experiment.

The small micro-autotroph fraction was initially dominated by Skeletonema sp. (95\% of counts), whereas Skeletonema constituted 55-85\%, Chaetoceros sp. 10-20\%, and Thalassionema sp. 5-20\% on Day 4 (Fig. 7a). On Day 10, Skeletonema sp. constituted $25-90 \%$ of the cells, with numbers forming a 
gradient with the lowest counts at high $L_{\mathrm{N}}$, whereas the counts of Chaetoceros sp. were 10-20\% of the total, forming an opposite gradient. The percentage of Thalassionema sp. had increased to $10-40 \%$, but with no trend relative to the nitrogen loading gradient (Fig. 7b). On Day 16, Thalassionema sp. was found in densities of $3-65 \%$ of the counts and inversely proportional to $L_{\mathrm{N}}$. At this time, Leptocylindrus sp. was present in an opposite gradient to Thalassionema sp. and constituted $3-83 \%$ of the counts. In addition, the counts of Cylindrotheca sp. constituted 10-30\% and those of Pseudonitzschia sp. $10-55 \%$ of total numbers, but with no particular relationship to the ammonium loading gradient (Fig. $7 \mathrm{c}$ ).

Succession of the community of large micro-autotrophs

From Days 0 to 4, cell numbers of Ceratulina sp. increased from 0 to around 50 cells $\mathrm{ml}^{-1}$ in all microcosms. After this, the numbers declined to close to 0 again on Day 10 but increased to about 30 cells ml $^{-1}$ in Treatments 1 and 6 and to 8 cells $\mathrm{ml}^{-1}$ in Treatment 8 at Day 16. The most prominent in terms of cell numbers was Thalassiosira sp., which increased from 2 cells $\mathrm{ml}^{-1}$ on Day 0 to approximately 150 cells ml $\mathrm{ml}^{-1}$ in most microcosms, and to around 400 cells $1^{-1}$ in microcosms 5 and 8 . In all microcosms, the maximum was reached on Day 10, after which the numbers declined again to $1-50$ cells $\mathrm{ml}^{-1}$ on Day 16 .

Thalassiosira sp. was the only micro-autotroph found in the sample at Time 0 . On Day 4, Thalassiosira sp. constituted $50-60 \%$ of the counts and Ceratulina sp. $15-45 \%$ at all $L_{\mathrm{N}}$ levels (Fig. $7 \mathrm{~d}$ ). On Day 10, Thalassiosira was again dominant, with $80-90 \%$ of the counts in all microcosms (Fig. 7e). The counts of Thalassiosira were $10-50 \%$ of the total counts on Day 16, with numbers forming a gradient with highest counts at low $L_{\mathrm{N}}$. At this time, Eucampia and Rhizosolenia, and to a lesser extent Ceratulina and Melosira, were beginning to dominate the cell counts (Fig. 7f), and some large dinoflagellates appeared at this time (Diplosalis sp., Dinophysis sp., Protoperidinium sp.), but not in dominating numbers (Fig. 7f).

\section{DISCUSSION}

\section{Response in the concentration of dissolved nutrients}

Phosphate was never completely depleted and varied between 0.2 and $0.6 \mu \mathrm{M}$ (Fig. 2). We know from experience that $0.25 \mu \mathrm{M} \mathrm{PO}_{4}$ can sustain consider- able production (Olsen et al. 2002). The positive relationship found between phosphate concentration and loading rate also indicates that phosphorus did not limit phytoplankton growth. Nitrate was completely depleted, and the low ammonium concentrations throughout the experiment confirm that all nitrogen added to the microcosms was immediately taken up by the plankton. Thus, the supply of nitrogen was limiting for the phytoplankton for all nutrient loading rates, despite the fact that the N:P ratio supplied was higher than natural N:P (Olsen \& Olsen 2008, Wang et al. 2013). Consequently, it was not surprising that the plankton biomass showed a positive relationship to nitrogen $\left(\mathrm{NH}_{4}\right)$ loading rate. The southern fjord region of Chile is characterized by low $\mathrm{NO}_{3}: \mathrm{PO}_{4}$ in surface water (Iriarte et al. 2007, 2013), and the nitrogen-limited scenario is therefore realistic. The silicon concentration remained below $2 \mu \mathrm{M}$, which can limit diatom growth (Egge \& Aksnes 1992). Therefore, the diatoms may have experienced co-limitation by silicic acid, although the constant supply of $\mathrm{Si}$ at a relatively high ratio with nitrogen maintained diatom dominance.

\section{Responses in POC and the biomass of plankton functional groups}

The linear response in total POC (biotic + detritus) at the final sampling on Day 16 in our experiment was similar to that obtained in experiments with similar gradients of nutrient loading in the northeast Atlantic and in the Baltic Sea (Olsen et al. 2006). Between 42 and $55 \%$ of POC was detritus in our microcosms (Fig. 4c). In the mesocosm experiments reported by Olsen et al. (2006), the detritus proportion of POC was around $30 \%$ in northeast Atlantic water, whereas it was $50 \%$ or even higher in some cases in the Baltic Sea. In the oligotrophic Mediterranean Sea, detritus constituted around $90 \%$ of POC (Olsen et al. 2006). Those mesocosms were deeper and were static bag systems. It is therefore likely that the measured POC in our microcosms was more affected by detritus because of the different sampling procedures. Our 351 microcosms were stirred before sampling, making it highly probable that a fraction of sedimented material was suspended and collected on our filters for POC, thereby becoming a component of detritus.

Pico-autotrophs were not counted in our experiment, but their contribution to total biomass was probably minor. In a later eutrophication experiment with mesocosms in the Comau fjord we quantified 
pico-cyanobacteria, and these disappeared from the mesocosms during enrichment (L. M. Olsen unpubl.). Olsen et al. (2006) also observed a reduction in the abundance of cyanobacteria after an initial increase in their mesocosms. The autotrophic fraction of the total biotic carbon was approximately $50 \%$ in our study (Fig. 4c), but around $90 \%$ in the northeast Atlantic and in the Baltic Sea in the study of Olsen et al. (2006); only in the Mediterranean Sea did Olsen et al. (2006) find an autotroph fraction which was similar to the present study (ca. $60 \%$ ). In the Mediterranean Sea, grazing by salps kept the phytoplankton biomass low (Olsen et al. 2006).

Our staining method for counting nanoflagellates was unable to discriminate autotrophs and heterotrophs, but in an earlier study in the same area, we counted almost equal abundance of heterotrophic and autotrophic nanoflagellates (L. M. Olsen unpubl.). If this distribution is valid for the present study, the autotroph fraction would be around $60 \%$. We also found a non-significant positive $\left(R^{2}=0.41, p=0.09\right)$ linear relationship between autotroph:heterotroph ratio and nutrient loading rate, but no dramatic shift in this ratio was observed in the experiment.

Because of the similarity of the early responses found for all treatments until Day 4 or 6, these were probably a result of the change in environment from the water column to the microcosms experienced by the plankton. The average biomass response to increasing nutrient loading rate was significantly positive for micro-autotrophs and micro-heterotrophs (Table 3), whereas we found no significant response for nanoflagellates and only a significant negative response for pico-heterotrophs at Day 6 (Fig. 3c,d). The micro-heterotrophs were presumably the main consumers of heterotrophic and autotrophic nanoflagellates (Sommer et al. 2005), and may have mitigated an increase in the biomass of this functional group (Fig. 3c). Olsen et al. (2007) found a similar response to eutrophication in Northeast Atlantic coastal water, with the highest biomass increase in nano- and micro-autotrophs consisting mainly of diatoms, as observed in the present study (Fig. 7). They used inverse modeling to show that at high nutrient loading rates, the increased carbon flow from the primary producers was primarily allocated through micro- and meso-heterotrophs. The main increase in biomass was found in these functional groups and in detritus, with a minor increase in biomass or carbon flow through picoplankton and nanoflagellates.

A more detailed study of the copepods in our microcosms showed that the copepods were mainly small calanoid species. On Day 16, the biomass ranged between 15 and $54 \mu \mathrm{g} \mathrm{Cl}^{-1}$ in the microcosms (Jensen 2012) and showed a non-significant linear trend with increasing ammonium loading rate at the final sampling (Table 3). The biomass of copepod nauplii was in the range of 0.14 to $1.27 \mu \mathrm{g} \mathrm{Cl}^{-1}$, and there was a significant linear trend with increasing ammonium loading rate on Day 16 of the experiment (Table 3). The ciliate community was dominated by aloricate ciliates (Jensen 2012). We chose to separate the phytoplankton counts between the small microautotrophs with a volume below $10000 \mu^{3}$ which are potentially also food for the micro-heterotrophs, and those that are larger and are only prone to predation by the copepods (Fig. 1). According to Sommer et al. (2005), the small calanoid copepod Acartia tonsa feeds on large and chain-forming diatoms, dinoflagellates, and ciliates, whereas the ciliates feed on nano-sized $(2-20 \mu \mathrm{m})$ heterotrophs and autotrophs, corresponding to the nanoflagellates and most likely also the smallest micro-autotrophs in our study. We added an equal number of copepods to all microcosms, and an experiment lasting for $16 \mathrm{~d}$ is too short to have a substantial response in the number of copepods because they have generation times of around 20 d (Landry 1983). Nevertheless, the numbers of copepod nauplii showed a clear response to the nutrient loading rate (Table 3 ).

Since the clearance rate of nauplii is an order of magnitude lower than that of adult copepods (Merrell \& Stoecker 1998), we can assume that the grazing pressure from the meso-heterotrophs was similar in all treatments throughout the experiment. Sánchez et al. (2011) found that Calanus australis in the Comau fjord fed on plankton in the size range of 5 to $65 \mu \mathrm{m}$ equivalent spherical diameter and had a preference for ciliates. Vadstein et al. (2004) demonstrated how phytoplankton biomass can increase by releasing the grazing pressure from ciliates on phytoplankton when copepod abundance is high. The positive response of micro-heterotroph biomass to increasing nutrient loading rate found in our experiment (Table 3) indicated that the copepods were not able to control the ciliate biomass. We registered a positive response in micro-autotroph biomass with increasing nutrient loading rate (Table 3), but after Day 6, the increase in total phytoplankton biomass with time was mainly due to an increase in large micro-autotrophs (Fig. 3b). Some of the larger diatoms are likely not optimally shaped prey for the grazers, e.g. Rhizosolenia sp. (Perissinotto 1992), and these species became numerous towards the end of the experiment (Fig. 7f). 


\section{Response in the community composition of micro-autotrophs}

The CCA of data from Days 10 and 16 showed that of the environmental variables, all nutrients that were depleted to limiting levels, the ammonium loading rate, and phytoplankton abundance were significant constraints on micro-autotroph community structure, whereas phosphate, which was not depleted, and the abundance of bacteria, nanoflagellates, and ciliates were not significant constraints. CCA axes 1 and 2 explained $61 \%$ of the variance in the community structure. In the CCA plot, axis 1 is related to depletion of the $\mathrm{NH}_{4}$ and the increase in phytoplankton abundance and ciliate abundance as a consequence of increased ammonium loading rate $\left(L_{\mathrm{N}}\right)$. The analysis indicates that the change in community structure is affected by the gradient in nutrient loading. On Day 10, there was also a significant positive linear relationship between loading rate of nutrients and diversity. On Day 16, these relationships were weaker. In the following discussion, we will try to elucidate the underlying mechanisms for this pattern of development by looking more closely at the changes in micro-autotroph community structure.

Diatoms became dominating in the community of micro-autotrophs throughout the experiment (Fig. 7). The molar Si:N ratios in deep water $(100 \mathrm{~m})$ in the Comau fjord and in the initial water for our experiment taken at $10 \mathrm{~m}$ depth were 0.71 and 0.59 , respectively. We chose a molar Si:N ratio of 1 for our additions, which is the average ratio found in mixed marine plankton (Redfield 1958) and a favorable ratio for diatoms which may then dominate the community according to several studies (Sommer 1998, Sommer et al. 2005). Hutchins \& Bruland (1998) found that the $\mathrm{Si}$ N uptake ratio for diatoms was close to 1 under conditions of no nutrient limitation. In the Comau fjord, new silicon can be supplied both from deep water and from fresh water rich in silicic acid that forms the surface brackish layer (Iriarte et al. 2013). Fresh water in rivers that drain into the Comau fjord has relatively low concentration of $\mathrm{PO}_{4}$ $(0-0.5 \mu \mathrm{M})$ and $\mathrm{NO}_{3}(0.3-2.5 \mu \mathrm{M})$, but considerably more Si (12.2-17.2 $\mu \mathrm{M}_{i}$ Iriarte et al. 2013). The concentration of silicic acid in the water column was relatively high in the euphotic zone compared with that in northeast Atlantic coastal water, which showed concentrations of 3 to $4 \mu \mathrm{M}$ in winter and close to 0 in summer (Solli 2013). A situation with nitrogen limitation of the phytoplankton and a dominance of diatoms in the micro-phytoplankton as found in our microcosms is very likely to be typical in the Comau fjord.
At the start of the experiment, Skeletonema sp. dominated the total micro-autograph counts, but between Days 4, 10, and 16, clear changes in the community of both small and large micro-autotrophs took place (Fig. 7). Most of the phytoplankton taxa that grew fastest were apparently subsequently grazed down, and the negative biomass relationship with increasing rate of nutrient loading indicated that the phytoplankton was removed more rapidly in the high-nutrient treatments. This pattern could be seen for Skeletonema sp. on Day 10 (Fig. 7b) and for Thalassionema sp. and Thalassiosira sp. on Day 16 (Fig. $7 \mathrm{c}, \mathrm{f})$, suggesting that these microalgae were preferred food items for the grazers and that they were consumed faster in the treatments with high nutrient loading rate that showed a higher density of micro-heterotrophs, and also higher biomass of copepods and higher density of nauplii. Also, the numbers of Chaetoceros sp. and Ceratulina sp. increased, before they became reduced to low numbers. Of the micro-autotrophs that became dominant towards the end of the experiment, some were pennate diatoms like Cylindrotheca sp. and Pseudonitzschia sp., but these also included the chain-forming Leptocylindrus sp. and the large cylindrical rod-shaped Rhizosolenia sp. (Fig. $7 \mathrm{C}, \mathrm{f}$ ). The 3 first genera are all weakly silicified elongated species with a relatively low surface:volume ratio (Alves-de-Souza et al. 2008). This could be a response to limiting concentrations of both inorganic nitrogen and silicon, and it is also possible that these cell types are less preferred as food for the grazers, as was reported for the large and elongated Rhizosolenia sp. by Perissinotto (1992), even if some copepods are able to eat Pseudonitzschia sp. (Maneiro et al. 2005). Sommer (1998) observed a similar succession of the phytoplankton at Si:N ratios that favored diatoms, with an increasing proportion of thin elongated species while the grazers selected non-elongated species. Most diatom species are not harmful, but some species of Pseudonitzschia sp. can be toxic, and species of Leptocylindrus and Rhizosolenia have been associated with harmful or nuisance blooms with fish mortalities in salmon cages in Chile (Buschmann et al. 2006, Iriarte et al. 2013).

We observed an increase in the Shannon diversity index for the micro-autotrophic community in all treatments after the inoculation, and the index was sustained at a higher level, even with low and no nutrient addition (Fig. 5). This suggests that some additional factor was affecting species diversity. On Day 10, we observed a significant positive linear relationship between nutrient loading rate and the 
Shannon diversity index $\left(\mathrm{R}^{2}=0.80, \mathrm{p}=0.003\right)$. The daily disturbance of the microcosms at the time of sampling and nutrient addition might have promoted diversity, as has been shown for physical disturbance elsewhere (Connell 1978, Moustaka-Gouni 1993, Flöder \& Sommer 1999, Irigoien et al. 2004). Disturbances of the upper water column are likely to happen occasionally in the fjord because of wave action, and the disturbance that took place in our microcosms is consistent with natural conditions. There is, however, a possibility that during calm periods with stratified water, the responses to nutrient enrichment could be different. In particular during such conditions, silicon may become depleted because of reduced mixing with silicon-rich deep water or the river-influenced top layer, and the dominance could shift from diatoms to other phytoplankton groups. For example, dinoflagellates may prevail under stratified conditions with high nutrient concentration (Margalef 1978, Sellner et al. 2001).

\section{Conclusions}

A positive linear carbon biomass response to nutrient loading rate was found for the micro-autotrophic, micro-heterotrophic, and meso-heterotrophic functional groups, which is a similar food web response to what was found in Northeast Atlantic water by Olsen et al. (2006). The biomasses of the picoheterotrophs and the nanoflagellates were mainly predator controlled.

For all nutrient addition rates, nitrogen became the limiting nutrient, and there was no indication that the relatively high N:P ratio characteristic of effluent from salmon aquaculture (Olsen \& Olsen 2008, Wang et al. 2013) changed the tendency towards P limitation. Both $\mathrm{N}$ limitation and the dominance of diatoms due to relatively high supply of $\mathrm{Si}$ are consistent with the natural conditions of the Comau fjord (Iriarte et al. 2007, 2013). The observed dominance of diatoms in the micro-autotroph community was likely caused by the Si:N supply ratio of 1 .

The positive biomass response of the micro-autotrophs to an increasing rate of nutrient loading originated in the succession of the diatom-dominated community towards either small, weakly silicified pennate or chain-forming cells with high surface to volume ratio, or large elongated or chain-forming species. This shape and/or size may make these cells more grazer resistant than other non-elongated or smaller species which appeared to be selectively consumed. Apparently, grazers promoted a succes- sion in the micro-autotroph community by removing some potentially successful competitors. The succession seemed to be similar for all nutrient loading rates, but faster at high loading rates. This could be a consequence of the higher abundance of predators in those microcosms due to higher primary production. The strong relationship between nutrient loading rate and both diversity and community composition on Day 10 could be due to this difference in the response rate of the grazers, whereas the weaker relationship on Day 16 could be because the whole community shifted into a more grazer-resistant one. The similarity of the succession at all loading rates implies that the same mechanisms are working at a wide range of productivity. How an increased abundance of copepods may alter this later is an open question, but if the next generation of copepods are also mainly of the same species, their ability to alter the micro-autotroph community may be limited, but they may reduce the abundance of ciliates and ease some of the grazing pressure on small microautotrophs and nanoflagellates.

Under conditions with strong stratification in the water column, the supply of new silicon from deep water or the brackish top layer might be reduced compared to our experimental supply, which could shift the dominance of the micro-autotroph community from diatoms to other groups, e.g. dinoflagellates. Therefore, a rich supply of silicic acid to Patagonian fjords may contribute to reduce dinoflagellate blooming events following increased nutrient input. A situation with reduced freshwater input, and thus reduced silicon input, to Patagonian fjords as a consequence of climate change (Rebolledo et al. 2005, Iriarte et al. 2010) in combination with anthropogenic eutrophication, may consequently alter the microautotroph community towards an increased proportion of dinoflagellates or other non-silicified species. In the Baltic Sea, a change from diatom to dinoflagellate dominance during the spring bloom has been observed, and nutrient enrichment experiments indicate that if the dinoflagellate inoculum is large enough at the start they will dominate a bloom even if silicon is available for diatoms (Kremp et al. 2008). This suggests that changes may occur in the phytoplankton community over time scales much longer than the presented experiment.

To have an idea of the magnitude of the nutrient loading in the Comau fjord compared with our experimental loading rates, we can make a rough estimate of volumetric loading rate. The fjord is approximately $35 \mathrm{~km}$ long and on average $4 \mathrm{~km}$ wide. If we assume the depth of water affected by nutrient loading from 
fish farms is $20 \mathrm{~m}$, then the volume of water affected is $2.8 \mathrm{~km}^{3}$. According to fish-feed-waste mass balance equations (Olsen \& Olsen 2008, Wang et al. 2012), the amount of ammonium released directly to the water from 1 fish farm which produces $10000 \mathrm{t}$ of fish per year (i.e. among the largest fish farms today) is $407 \mathrm{t} \mathrm{yr}^{-1}$. Averaged over the whole year, the volumetric loading rate will be $0.03 \mu \mathrm{mol} \mathrm{NH} \mathrm{N}_{4} \mathrm{l}^{-1} \mathrm{~d}^{-1}$. This is $10 \%$ of what we call natural loading in our experiment (Treatment 2), which is derived from calculations by Olsen et al. (2006) for the natural loading rate for inorganic nitrogen from deep water to the euphotic zone in the north Atlantic coastal water. Accordingly, if there were 10 fish farms of this magnitude in the Comau fjord, they would release an amount of nitrogen comparable to the natural loading rate. This is a crude estimate, and many factors may modify the volumetric loading rate, e.g. the depth affected by fish farm effluent may be different, water currents and water exchange in the fjord could cause variations in the dilution rates, and the yearly production at farms in the Comau fjord certainly varies. According to the maps of the Subsecretaria de Pesca y Acuicultura (www.subpesca.cl), there are approximately 20 fish farm concessions in the Comau fjord. Hypothetically, if all of these released the same amount of ammonium as in our calculations above, then the total volumetric loading rate would be $0.6 \mu \mathrm{mol} \mathrm{NH} \mathrm{N}^{-1} \mathrm{~d}^{-1}$. Given that the natural loading rate is $0.3 \mu \mathrm{mol} \mathrm{NH} \mathrm{N}^{-1} \mathrm{~d}^{-1}$, the total loading rate in the fjord would be $0.9 \mu \mathrm{mol} \mathrm{NH} \mathrm{NH}^{-1} \mathrm{~d}^{-1}$. This is in the middle of our experimental gradient (Table 1). Based on the synthesis of several eutrophication studies, Olsen et al. $(2006,2007)$ concluded that the limit of inorganic nitrogen above which ecosystem degradation may occur in Atlantic water is $1 \mu \mathrm{mol} \mathrm{l}^{-1}$ $\mathrm{d}^{-1}$. In their studies, the main effects were increased phytoplankton biomass and detritus mass, which results in increased sedimentation and possibly oxygen depletion. Our study showed a similar response in the production of phytoplankton and detritus, as well as a change in the phytoplankton community composition. The rate and amplitude of the effects were proportional to the nutrient loading rate. The actual response to increased nutrient loading in the Comau fjord planktonic ecosystem depends heavily on the water exchange and mixing rate of the euphotic layer.

Acknowledgements. We thank Adrian Levrel, Harriet de Ruiter, Ingvil Jensen, Can Bizsel, Pamela A. Labbé Ibáñez, Mauricio Espinoza, Nelson Silva, and all of our friends and colleagues at the Huinay Field Station for assistance and technical help. Thanks to the editor and anonymous re- viewers for constructive comments. This experiment was undertaken as a part of the WAFOW project at NTNU, Department of Biology, financed by the Norwegian Research Council (project 193661). K.L.H. acknowledges a FONDECYT 11110190 grant from CONICYT Chile. L.M.O. acknowledges the project CINTERA (NRC 216607) at NTNU. This is publication no. 117 of the Huinay Scientific Field Station.

\section{LITERATURE CITED}

Alves-de-Souza C, Gonzales MT, Iriarte JL (2008) Functional groups in marine phytoplankton assemblages dominated by diatoms in fjords of southern Chile. J Plankton Res 30:1233-1243

Atlas EL, Gordon LI, Hager SW, Park PK (1971) A practical manual for use of the Technicon Autoanalyzer in seawater nutrient analyses (revised). Tech Rep 215. Department of Oceanography, Oregon State University, Corvallis, OR

Buschmann AH, Riquelme VA, Hernandez-Gonzalez MC, Varela DA and others (2006) A review of the impacts of salmonid farming on marine coastal ecosystems in the southeast Pacific. ICES J Mar Sci 63:1338-1345

Buschmann AH, Cabello F, Young K, Carvajal J, Varela DA, Henríquez L (2009) Salmon aquaculture and coastal ecosystem health in Chile: analysis of regulations, environmental impacts and bioremediation systems. Ocean Coast Manag 52:243-249

Cloern J (2001) Our evolving conceptual model of the coastal eutrophication problem. Mar Ecol Prog Ser 210: 223-253

Conley DJ, Schelske CL, Stoermer EF (1993) Modification of the biogeochemical cycle of silica with eutrophication. Mar Ecol Prog Ser 101:179-192

> Connell JH (1978) Diversity in tropical rain forests and coral reefs. Science 199:1302-1310

Egge JK, Aksnes DL (1992) Silicate as regulating nutrient in phytoplankton competition. Mar Ecol Prog Ser 83: 281-289

Flöder S, Sommer U (1999) Diversity in planktonic communities: an experimental test of the intermediate disturbance hypothesis. Limnol Oceanogr 44:1114-1119

Grasshoff K, Ehrhardt M, Kremling F (1983) Methods of seawater analysis, 2nd edn. Verlag Chemie, Weinheim

Hass L (1982) Improved epifluorescence microscopy for observing planktonic micro-organisms. Ann Inst Oceanogr 58:261-266

Hillebrand H, Durselen CD, Kirschtel D, Pollingher U, Zohary $\mathrm{T}$ (1999) Biovolume calculation for pelagic and benthic microalgae. J Phycol 35:403-424

Hutchins DA, Bruland KW (1998) Iron-limited diatom growth and Si:N uptake ratios in a coastal upwelling regime. Nature 393:561-564

Iriarte JL, Gonzalez HE, Liu KK, Rivas C, Valenzuela C (2007) Spatial and temporal variability of chlorophyll and primary productivity in surface waters of southern Chile (41.5-43ํ S). Estuar Coast Shelf Sci 74:471-480

> Iriarte JL, González HE, Nahuelhual L (2010) Patagonian fjord ecosystems in southern Chile as a highly vulnerable region: problems and needs. Ambio 39:463-466

> Iriarte JL, Pantoja S, González HE, Silva G and others (2013) Assessing the micro-phytoplankton response to nitrate in Comau Fjord $\left(42^{\circ} \mathrm{S}\right)$ in Patagonia (Chile), using a micro- 
cosms approach. Environ Monit Assess 185:5055-5070

Irigoien X, Huisman J, Harris RP (2004) Global biodiversity patterns of marine phytoplankton and zooplankton. Nature 429:863-867

Jensen IN (2012) The effect of nutrient release from fish farms on the lower trophic levels of the marine food web in North Patagonia, Chile. MSc thesis, Norwegian University of Science and Technology (NTNU), Trondheim

Kremp A, Tamminen T, Spilling K (2008) Dinoflagellate bloom formation in natural assemblages with diatoms: nutrient competition and growth strategies in Baltic spring phytoplankton. Aquat Microb Ecol 50:181-196

> Landry MR (1983) The development of marine calanoid copepods with comment on the isochronal rule. Limnol Oceanogr 28:614-624

Lee S, Fuhrman J (1987) Relationship between biovolume and biomass of naturally-derived marine bacterioplankton. Appl Environ Microbiol 53:1298-1303

Maneiro I, Iglesias P, Guisande C, Riveiro I, Barreiro A, Zervoudaki S, Graneli E (2005) Fate of domoic acid ingested by the copepod Acartia clausi. Mar Biol 148:123-130

Margalef R (1978) Life-forms as survival alternatives in an unstable environment. Oceanol Acta 1:493-509

- Mayr C, Rebolledo L, Schulte K, Schuster A, Zolitschka B, Försterra G, Häussermann V (2014) Responses of nitrogen and carbon deposition rates in Comau Fjord $\left(42^{\circ} \mathrm{S}\right.$, southern Chile) to natural and anthropogenic impacts during the last century. Cont Shelf Res 78:29-38

Menden-Deuer S, Lessard EJ (2000) Carbon to volume relationships for dinoflagellates, diatoms, and other protist plankton. Limnol Oceanogr 45:569-579

Merrell JR, Stoecker DK (1998) Differential grazing on protozoan microplankton by developmental stages of the calanoid copepod Eurytemora affinis Poppe. J Plankton Res 20:289-304

- Moustaka-Gouni M (1993) Phytoplankton succession and diversity in a warm monomictic, relatively shallow lake: Lake Volvi, Macedonia, Greece. Hydrobiologia 249: 33-42

> Olsen LM, Reinertsen H, Vadstein O (2002) Can phosphorus limitation inhibit dissolved organic carbon consumption in aquatic microbial food webs? A study of three food web structures in microcosms. Microb Ecol 43:353-366

Olsen Y, Olsen LM (2008) Environmental impact of aquaculture on coastal planktonic ecosystems. In: Tsukamoto $\mathrm{K}$, Kawamura T, Takeuchi T, Beard TD Jr, Kaiser MJ (eds) Fisheries for global welfare and environment, 5th World Fisheries Congress 2008, Terrapub, Tokyo, p 181-196

Olsen Y, Agusti S, Andersen T, Duarte CM and others (2006) A comparative study of responses in planktonic food web structure and function in contrasting European coastal waters exposed to experimental nutrient addition. Limnol Oceanogr 51:488-503

Olsen Y, Andersen T, Gismervik I, Vadstein O (2007) Protozoan and metazoan zooplankton-mediated carbon flows in nutrient-enriched coastal planktonic communities. Mar Ecol Prog Ser 331:67-83

Perissinotto R (1992) Mesozooplankton size-selectivity and grazing impact on the phytoplankton community of the Prince Edward Archipelago (Southern Ocean). Mar Ecol Prog Ser 79:243-258

Philippart CJM, Cadee GC, van Raaphorst W, Riegman R (2000) Long-term phytoplankton-nutrient interactions in

Editorial responsibility: Adam Hughes,

Oban, UK a shallow coastal sea: algal community structure, nutrient budgets, and denitrification potential. Limnol Oceanogr 45:131-144

> Pitta P, Tsapakis M, Apostolaki ET, Tsagaraki T, Holmer M, Karakassis I (2009) 'Ghost nutrients' from fish farms are transferred up the food web by phytoplankton grazers. Mar Ecol Prog Ser 374:1-6

> Poole HH, Atkins WR (1929) Photo-electronic measurements of submarine illumination throughout the year. J Mar Biol Assoc UK 16:297-394

Porter K, Feig Y (1980) The use of DAPI for identifying and counting aquatic microflora. Limnol Oceanogr 25: 943-948

R Development Core Team (2008) R: a language and environment for statistical computing. R Foundation for Statistical Computing, Vienna. www.R-project.org

> Rebolledo L, Lange CB, Figueroa D, Pantoja S, Munoz P, Castro R (2005) 20th century fluctuations in the abundance of siliceous microorganisms preserved in the sediments of the Puyuhuapi channel $\left(44^{\circ} \mathrm{S}\right)$, Chile. Rev Chil Hist Nat 78:469-488

Redfield AC (1958) The biological control of chemical factors in the environment. Am Sci 46:205-221

Sánchez N, González HE, Iriarte JL (2011) Trophic interactions of pelagic crustaceans in Comau Fjord (Chile): their role in the food web structure. J Plankton Res 33: 1212-1229

> Sellner KG, Sellner SG, Lacouture RV, Magnien RE (2001) Excessive nutrients select for dinoflagellates in the stratified Patapsco River estuary: Margalef reigns. Mar Ecol Prog Ser 220:93-102

Skarbøvik E, Stålnacke P, Selvik JR, Aakerøy PA, Høgåsen T, Kaste Ø (2012) Elvetilførselsprogrammet (RID) 20 års overvåking av tilførsler til norske kystområder (1990-2009). NIVA Rep no. 6235-2011. NIVA, Oslo

Solli CM (2013) Macronutrient distribution in relation to waste emission from aquaculture activities. A field study in Trondheimsfjorden. MSc thesis. Norwegian University of Science and Technology (NTNU), Trondheim

Sommer U (1998) Silicate and the functional geometry of marine phytoplankton. J Plankton Res 20:1853-1859

Sommer U, Hansen T, Blum O, Holzner N, Vadstein O, Stibor H (2005) Copepod and microzooplankton grazing in mesocosms fertilised with different Si:N ratios: no overlap between food spectra and Si:N influence on zooplankton trophic level. Oecologia 142:274-283

Utermöhl H (1958) Zur Vervollkommnung der quantitativen Phytoplankton-Methodik. Mitt Int Ver Theor Angew Limnol 9:1-38

> Vadstein O, Stibor H, Lippert B, Løseth K, Roederer W, Sundt-Hansen LE, Olsen Y (2004) Moderate increase in the biomass of omnivorous copepods may ease grazing control of planktonic algae. Mar Ecol Prog Ser 270: 199-207

> Wang X, Olsen LM, Reitan KI, Olsen Y (2012) Discharge of nutrient wastes from salmon farms: environmental effects, and potential for integrated multi-trophic aquaculture. Aquacult Environ Interact 2:267-283

Wang X, Andresen K, Handå A, Jensen B, Reitan KI, Olsen Y (2013) Chemical composition and release rate of waste discharge from an Atlantic salmon farm with an evaluation of IMTA feasibility. Aquacult Environ Interact 4: $147-162$

Submitted: June 30, 2014; Accepted: September 18, 2014

Proofs received from author(s): October 22, 2014 